\title{
TIAGO LUÍS PAVINATTO GONÇALVES
}

\section{Da condição do fanático religioso no Direito civil}

Tese apresentada à Banca Examinadora do Programa de Pós-Graduação em Direito stricto sensu da Faculdade de Direito da Universidade de São Paulo do Largo São Francisco como exigência parcial para obtenção do título de Doutor em Direito, na área de concentração em Direito Civil, sob a orientação da Professora Associada Dra. Daisy Gogliano.

UNIVERSIDADE DE SÃO PAULO

FACULDADE DE DIREITO

São Paulo-SP

2018 
GONÇALVES, Tiago Luís Pavinatto

Da condição do fanático religioso no Direito civil/Tiago Luís Pavinatto Gonçalves.

Tese (Doutoramento em Direito Civil) sob a orientação da Professora Associada Dra.

Daisy Gogliano - São Paulo: Faculdade de Direito da Universidade de São Paulo do Largo São Francisco, 2018. 271 f. 
FOLHA DE APROVAÇÃO (Para uso da Banca Examinadora)

Prof. (a)

Julgamento:

Prof. (a)

Julgamento:

Prof. (a)

Julgamento:

Prof. (a)

Julgamento:

Prof. (a)

Julgamento:
Instituição:

Assinatura:

Instituição:

Assinatura:

Instituição:

Assinatura:

Instituição:

Assinatura:

Instituição:

Assinatura: 
AGRADECIMENTOS

O primeiro desta breve série de agradecimentos é para nossa Orientadora, a Professora Associada Dra. Daisy Gogliano, jurista ímpar e de primeira grandeza com inigualável conhecimento jurídico lastreado em sólida cultura filosófica, verdadeira amante dos (bons) livros e leitora sem par, mas de quem a Titularidade tão merecida foi lamentavelmente subtraída. A ela, toda nossa admiração e gratidão não só por acreditar em nós e em nossos temas tão incomuns desde o Mestrado, mas também pelo genuíno carinho e real interesse para com nosso trabalho demonstrados ao longo de todo o processo.

Ao Dr. Washington da Silva Vieira Sobrinho, agradecemos não só pelo incentivo de sempre, mas também pelas possibilidades que abriu para que os créditos, as pesquisas e as leituras fossem cumpridos por nós da forma mais serena possível. Obrigado pelo valioso bem que é o tempo - e, por falar em tempo, ao tempo dispendido e ao espírito franciscano do Dr. Walter Pugliano pela revisão do nosso texto.

Agradecemos também à Professora Titular Dra. Teresa Ancona Lopez e à Dra. Márcia Lenci Viscomi por não deixarem, em diversas oportunidades, que desistíssemos da empreitada.

Um último agradecimento nominal: ao Tomas Auksas, por ter nos devolvido a alegria e dado inspiração para a redação desta tese em tempo invejável. Sem ele, todos os esforços e etapas anteriores corriam o risco de ter sido em vão.

Por fim, aos loucos de todo o gênero. 
Suscipiat Dominus sacrificium de manibus tuis ad laudem et gloriam nominis sui, ad utilitatem quoque nostram totiusque Ecclesice suce santactoe. 
Ultima hominis felicitas est in contemplatione veritatis. (São Tomás de Aquino, Summa contra Gentiles, III, 37).

Dicit ei Pilatus: "Quid est veritas?"

(Jo 18,38)

"Se há uma verdade é que a verdade está em jogo nas lutas"

(Pierre Boudieu, O Poder Simbólico, p. 293) 


\section{RESUMO}

Tiago Luís Pavinatto Gonçalves. Da condição do fanático religioso no Direito civil. 2018. 267 f. Doutorado - Faculdade de Direito, Universidade de São Paulo, São Paulo, 2018.

É plenamente capaz para o exercício pessoal dos atos da vida civil, um sujeito religioso fanático que represente, por sua conduta confessional, potencial risco de danos ou que, efetivamente, cause prejuízos para si ou para terceiros? Sua conduta confessional fanática deve permanecer irrestrita frente à garantia da inviolabilidade da liberdade de consciência e de crença e do livre exercício dos cultos religiosos assegurada pelo Estado Democrático de Direito no atual contexto multicultural? Apesar do preceito constitucional, uma dupla negativa é possível se verificada a essência, a natureza jurídica do fanatismo. Em sendo farta a verificação fatual de que a vivência religiosa fundamentalista pode levar a situações dramáticas que colocam em perigo a própria vida, em diversos aspectos, do sujeito e identificado o direito fundamental da liberdade religiosa como uma fronteira entre o individual e o coletivo, o Direito civil, ao tratar da capacidade das pessoas naturais, do poder familiar, dos deveres conjugais e parentais, do abuso do direito e da coação, além do seu papel de agente modificador dos efeitos dos direitos fundamentais nos conflitos de Direito privado, apresenta-se como ferramenta mais apta e menos traumática para lidar com a problemática. Assim é que, a partir da leitura das conclusões mais modernas das ciências da mente (Psicologia, Psiquiatria e Neurociências) sobre os efeitos da Religião sobre o comportamento e a saúde mental e física das pessoas, diagnosticado o fanatismo religioso como sintoma de transtornos mentais, que nele encontram terreno fértil para manifestação ou agravamento, encontramos a sua natureza jurídica, o que torna possível o enquadramento legal do fanático como sujeito relativamente incapaz e passível, portanto, de sofrer algumas privações que deverão ser sempre estabelecidas casuisticamente na sentença de sua curatela.

Palavras-chave: capacidade; incapacidades; transtorno mental; direitos fundamentais; liberdade religiosa; religião; laicismo; tolerância; fanatismo; fundamentalismo; radicalismo; hiperreligiosidade; ultra ortodoxia; coação; abuso do direito. 


\begin{abstract}
Tiago Luís Pavinatto Gonçalves. The religious fanatic person condition in the civil Law. 2018. 267 p. Doctorate - Law School, University of São Paulo, São Paulo, 2018.

Is the fanatical religious one capable of performing the acts of civil life on his own if his confessional conduct poses a risk of harm or, in fact, causes harm to himself or others? Must his fanatical confessional action must remain unrestricted because of the freedom of conscience, belief and religious cults inviolability, which is assured by the Democratic State of Right in the current multicultural context? Despite this constitutional precept, a double negative is possible if we verify the legal nature of the fanaticism, which is in its essence. It is widely described that religious fundamentalist experiences can lead to dramatic situations that endanger one's own life of the person in various aspects; as well identified, the fundamental right of religious freedom is a border between the individual and the collective; so the Civil law, in dealing with the capacity of natural persons, family power, conjugal and parental duties, abuse of rights and coercion, and its role as modifying agent of the fundamental rights effects in private Law conflicts, presents as the more apt and less traumatic tool to deal with such a problem. Moreover, from the most recent conclusions of the mind sciences (Psychology, Psychiatry and Neurosciences) on the effects of Religion on behavioral, mental and physical health corroborates religious fanaticism as a symptom of mental disorders, which find in it a fertile ground of manifestation or aggravation. It is in this scientific paradigm where we find the legal nature of fanaticism, which makes possible to legally classify the fanatic person as one that is relatively incapable and therefore is liable to suffer some deprivations that should always be established casuistically in the sentence of his interdiction.
\end{abstract}

Keywords: capacity; disabilities; mental disorder; fundamental rights; religious freedom; religion; secularism; tolerance; fanaticism; fundamentalism; radicalism; hyperreligiosity; ultra orthodoxy; coercion; abuse of rights. 


\section{RIASSUNTO}

Tiago Luís Pavinatto Gonçalves. La condizione del religioso fanatico nel Diritto civile. 2018. 267 f. Dottorato - Facoltà di Giurisprudenza, Università di São Paulo, 2018.

È una persona religiosa fanatica capace di esercitare personalmente gli atti della vita civile se rappresenta, con la sua condotta confessionale, un potenziale rischio di danno o, di fatto, provoca danni a se stesso o agli altri? La loro fanatica condotta confessionale deve rimanere illimitata a causa della inviolabilità della libertà di coscienza e convinzione e del libero esercizio dei culti religiose assicurata dallo Stato Democratico di Diritto nell'attuale contesto multiculturale? Nonostante il precetto costituzionale, è possibile una doppia negazione se si verifica l'essenza, la natura giuridica del fanatismo. Il fatto che l'esperienza religiosa fondamentalista possa portare a situazioni drammatiche che mettono in pericolo la vita stessa della persona in vari aspetti e identificare il diritto fondamentale della libertà religiosa come una frontiera tra l'individuo e il collettivo, il Diritto civile, nel trattare con la capacità delle persone, il potere familiare, i doveri coniugali e parentale, l'abuso del diritto e la coercizione, oltre al suo ruolo di agente che modifica gli effetti dei diritti fondamentali nei conflitti di Diritto privato, viene presentato come lo strumento più adatto e meno traumatico per affrontare il problema. Quindi, dalla lettura delle conclusioni più recenti delle scienze della mente (Psicologia, Psichiatria e Neuroscienze) sugli effetti della Religione sul comportamento e sulla salute mentale e fisica delle persone e diagnosticare il fanatismo religioso come sintomo di disturbi mentali, che trovano in esso terreno fertile per loro manifestazione o aggravamento, troviamo la natura giuridica del fanatismo, che rende possibile la struttura legale del fanatico come soggetto relativamente incapace e quindi soggetto a soffrire di alcune privazioni che dovrebbero sempre essere stabilite caso per caso nella sentenza della sua inabilitazione.

Parole chiave: capacità; disabilità; disordine mentale; diritti fondamentali; libertà religiosa; religione; secolarismo; tolleranza; fanatismo; fondamentalismo; radicalismo; iper-religiosotà; ultra ortodossia; coercizione; abuso del diritto. 
SUMÁRIO

\section{CAPÍTULO SEGUNDO}

II.1. DAS PESSOAS NATURAIS: PERSONALIDADE E CAPACIDADE

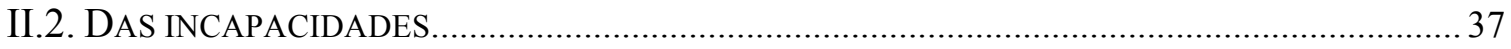

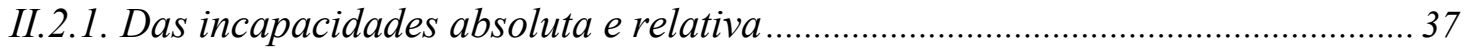

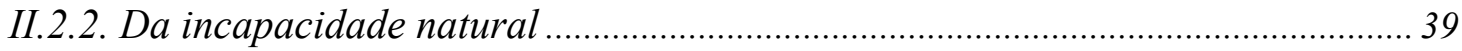

II.2.3. Do deficiente Estatuto da Pessoa com Deficiência ............................................. 44

Da retomada parcial das incapacidades e das interdições a partir da vigência do

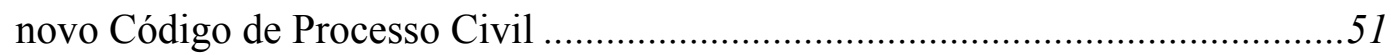




\section{CAPÍTULO TERCEIRO}

\section{DIREITOS FUNDAMENTAIS E DIREITO CIVIL}

III.1. DA INFLUÊNCIA DOS DIREITOS FUNDAMENTAIS SOBRE O COMPORTAMENTO DAS PESSOAS DE DIREITO PRIVADO

III.2. DA INFLUÊNCIA DOS DIREITOS FUNDAMENTAIS SOBRE A APLICAÇÃO E O DESENVOLVIMENTO DO DIREITO CIVIL

III.3. DA MODIFICAÇÃO DOS EFEITOS DOS DIREITOS FUNDAMENTAIS: DAS RESTRIÇÕES NÃO EXPRESSAMENTE AUTORIZADAS PELA CONSTITUIÇÃO

\section{CAPÍTULO QUARTO}

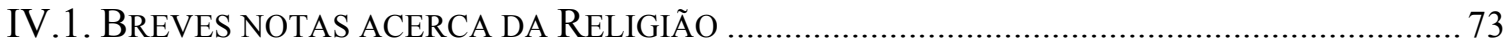

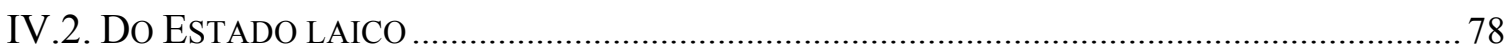

IV.2.1. Do Estado laico no atual contexto multicultural ................................................ 84

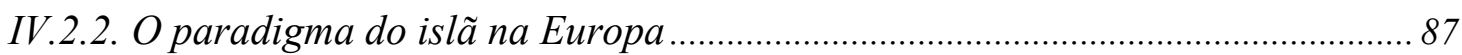

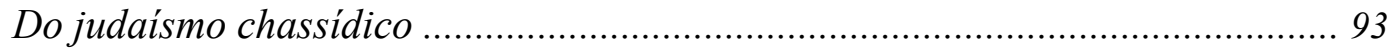

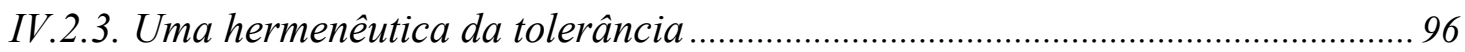

IV.2.4. Da prática do laicismo na esfera privada e da Religião no controle do Estado

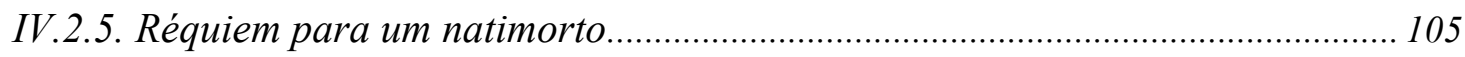

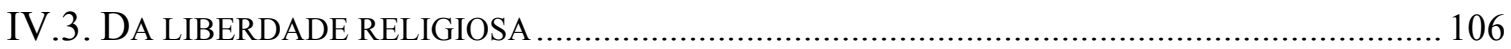

IV.3.1. Da tolerância e do laicismo dentro da própria casa .......................................... 111 
IV.3.2. Da recusa de tratamento médico por motivo religioso: o caso paradigmático das testemunhas de Jeová e seus desdobramentos

IV.3.2.A. Da recusa de tratamento a filho menor por motivo religioso

IV.3.2.B. Da inesperada iminência de risco de morte estando inconsciente a testemunha de Jeová durante o procedimento cirúrgico

IV.3.3. Do uso sagrado de substâncias proibidas.

IV.3.5. Da liberdade religiosa e de expressão e dos discursos de ódio e intolerância

IV.3.7. O Direito e o futuro da fé.

\section{IV.4. DA APLICAÇÃo E DO DESENVOLVIMENTO DO DiREITO CIVIL NO ÂMBITO DO ESTADO}

IV.4.1. Da capacidade civil e do exercício da liberdade religiosa

IV.4.2. Do poder familiar, dos deveres com a prole e do exercício da liberdade religiosa

IV.4.3. Da relação conjugal e paterna e do exercício da liberdade religiosa.

IV.4.4. Da coação no exercício da liberdade religiosa 149

IV.4.5. Do abuso do direito no exercício da liberdade religiosa 150

IV.4.6. Da incapacidade natural no exercício da liberdade religiosa.

IV.4.7. Da interface entre o abuso do direito, a coação moral e a incapacidade natural no exercício da liberdade religiosa

IV.4.8. Dos direitos do consumidor e do exercício da liberdade religiosa.

IV.4.9. Da tutela de urgência na perspectiva dos direitos fundamentais e de outras medidas processuais. 


\section{CAPÍTULO QUINTO}

V.1. PADRES, SANITARISTAS E PSIQUIATRAS: A EVOLUÇÃO DA PSIQUIATRIA. 167

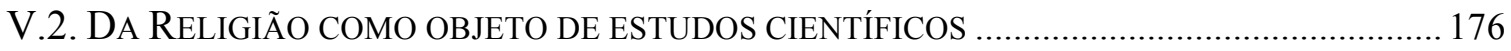

V.2.1. Do comportamento religioso nas Neurociências .............................................. 177

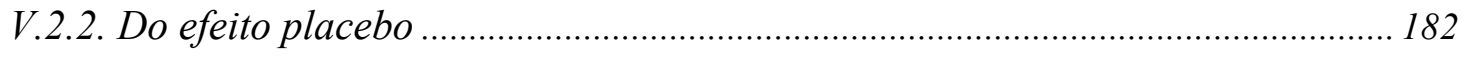

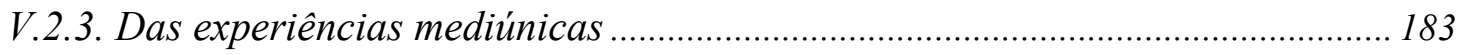

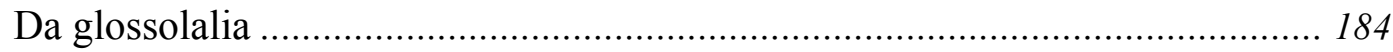

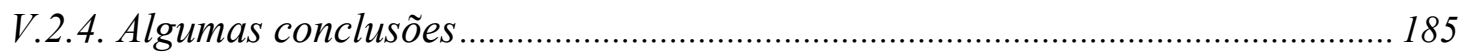

V.3. DO FANATISMO RELIGIOSO COMO TRANSTORNO OU SINTOMA DE TRANSTORNO MENTAL

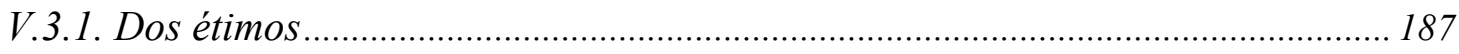

V.3.2. Do fanatismo religioso como um problema da modernidade ............................. 189

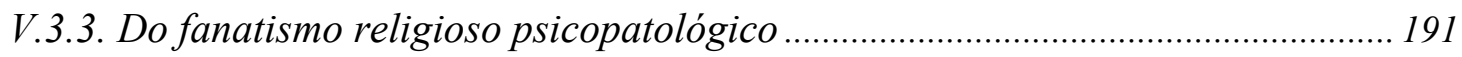

V.3.3.A. Da contribuição das pesquisas por neuroimagens ............................ 198

V.3.3.B. Do fanatismo através do condicionamento cerebral .......................... 198

V.3.3.B.1. Do componente etário ..................................................... 201

V.3.3.B.2. Da lavagem cerebral .................................................... 202

V.3.3.B.3. Do fanatismo coletivo ........................................................... 206

V.3.3.B.4. Do fanatismo infanticida em Novo Mundo ............................. 207

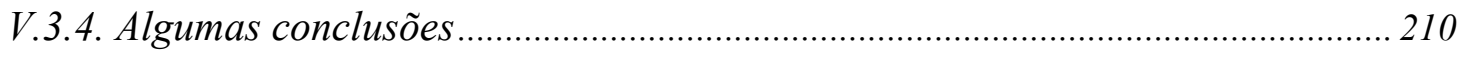

V.4. Do FANÁTICO RELIGIOSO COMO SUJEITO RELATIVAMENTE INCAPAZ ...........................2213

V.4.1. Da conveniência da curatela do fanático religioso e da delimitação das suas

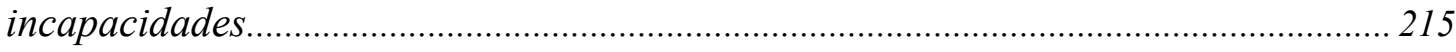

V.4.1.A. Da contribuição à efetivação do princípio da precaução ..................... 217 
V.4.1.B. Da contribuição à saúde pública

V.4.1.C. Da contribuição à segurança pública ............................................. 219

V.4.1.D. Da contribuição aos direitos da criança e do adolescente .................. 220

V.4.1.E. Das possíveis privações aplicáveis ao fanático religioso curatelado .. 222

V.4.2. Dos óbices no Estatuto da Pessoa com Deficiência

V.4.3. Da contribuição de tribunais quebequenses e franceses à matéria 224

V.4.4. De outros fanatismos: política e futebol 226

CAPÍTULO SEXTO

CONCLUSÕES E PROPOSTA DE REVISÃO LEGAL 231

NOTAS FINAIS

239

BIBLIOGRAFIA 


\section{NOTAS PRÉVIAS}

"Das Zeitungslesen des Morgens ist eine Art von realistischem Morgensegen."1

No nosso vernáculo, diria Hegel: "A leitura matutina do jornal é uma espécie de prece realista da manhã."

Atribuindo-nos o predicado realista, partimos para a análise do noticiário:

No Município paranaense de Cascavel, Maria Clara Ramalho tinha de 6 anos quando foi espancada e morta pela mãe, Vanessa do Nascimento, que alegou ser esse o plano de Deus frente ao demônio incorporado na menina ${ }^{2}$.

Entre 1997 e 2013 em Rotherham, norte da Inglaterra, foram vítimas de exploração sexual mais de 1400 meninas, muitas delas com 11 anos de idade, por um grupo de imigrantes paquistaneses que perceberam uma brecha legislativa para impunidade, uma vez que as autoridades locais se mantinham omissas frente aos costumes retrógrados

${ }^{1}$ HEGEL, Georg Wilhelm Friedrich. Aphorismen aus der jenenser zeit. In: HOFFMEISTER, Johannes (Org.). Dokumente zu Hegels Entwicklung. Stuttgard-Bad Cannstat: Frommann, 1974, p. 360.

${ }^{2}$ MÃE diz que matou filha para 'tirar o demônio'. O Estado de S. Paulo, São Paulo, 31 jul. 2014, p. A16. 
praticados pela comunidade muçulmana local, incluindo o casamento forçado com crianças ${ }^{3}$.

$* * *$

Dois homens encapuzados e vestindo roupas militares, com fuzis automáticos AK47, um lançador de granadas e cintos com munição, estacionaram um Citroën C3 preto próximo à sede do jornal Charlie Hebdo em Paris. Eram os irmãos Chérif Kouachi, de 32 anos, e Said Kouachi, de 34, franceses descendentes de argelinos. Eles se aproximaram da porta do edifício e forçaram a cartunista Corinne Rey, que fora pegar a filha no jardim de infância, a digitar o código no interfone para abrir a porta. Em francês perfeito, eles se apresentaram como sendo da Al Qaeda. "Não vou te matar porque você é uma mulher. Nós não matamos mulheres. Mas você tem de se converter ao Islã, ler o Corão e se cobrir", disse um deles a Corinne. Na recepção, eles atiraram contra um funcionário da empresa Sodexo, responsável pelo serviço de manutenção do prédio. Subindo as escadas, os dois perguntavam por Charb, o apelido do diretor do jornal, Stéphane Charbonnier, de 43 anos. Gritavam "Alá é Grande" e "Vamos vingar o profeta Maomé”. Dentro da redação, encontraram jornalistas e cartunistas reunidos para decidir os assuntos que seriam abordados na próxima edição. Separaram homens de mulheres e chamaram os profissionais pelo seu nome. Rajadas de tiros começaram a ser ouvidas enquanto as pessoas tentavam se esconder embaixo das mesas. O local ficou cheio de corpos (12 foram mortos), sangue e cacos de vidro ${ }^{4}$.

$$
* * *
$$

O grupo Boko Haram, uma espantosa falange de assassinos que atua na Nigéria, escondeu uma bomba debaixo da roupa de uma garota de 10 anos, obrigada a se detonar num ataque suicida em um mercado na cidade de Maiduguri, no nordeste do país. Vinte pessoas morreram. Três dias depois, o Estado Islâmico (Isis), exército fundamentalista e sanguinário que se supera em crueldade a cada dia na Síria e no Iraque, divulgou um vídeo na internet em que um garoto, também com cerca de 10 anos, executa, com tiros na nuca,

\footnotetext{
${ }^{3}$ A cegueira da tolerância. Veja, edição 2389, ano 47, no 36, p. 76-77, 3 set. 2014.

${ }^{4}$ TEIXEIRA, Duda; CARNEIRO, Felipe. A indignação do mundo contra as trevas. Veja, edição 2408, ano $48, n^{\circ} 2$, p. 52-66, 14 jan. 2015.
} 
dois homens acusados de serem espiões russos. Diz o garoto: "Eu serei aquele que vai massacrar os infiéis. Serei um soldado da jihad. Se Alá quiser",

Omar Abdel Hamid Hussein, de 22 anos, atirou contra um café onde ocorria um debate sobre liberdade de expressão em Copenhague. Matou uma pessoa e fugiu. Entre os participantes do evento, Lars Vilks, o artista sueco que caricaturou Maomé em 2007. Horas depois, o mesmo Omar atacou uma sinagoga na capital dinamarquesa, matando o segurança e ferindo dois policiais ${ }^{6}$.

O Estado Islâmico divulga vídeo no qual alguns de seus integrantes decapitam 21 cristãos coptas em uma praia na Líbia ${ }^{7}$.

Dois homens mascarados invadiram o território palestino de Duma na Cisjordânia. Eles quebraram os vidros de duas casas e lançaram coquetéis molotov. Um bebê de 1 ano morreu queimado, seus pais e seu irmão tiveram queimaduras graves. Do lado de fora da casa, os criminosos picharam "vingança" e "vida longa ao rei Messias".

$$
* * *
$$

Um judeu ortodoxo esfaqueou seis pessoas durante a parada gay de Jerusalém e matou uma estudante de 16 anos $^{9}$.

Três grupos de terroristas armados com rifles, granadas e bombas presas ao corpo assassinaram 129 pessoas de dezenove nacionalidades nos arredores do Stade de France, no Bataclan, em um restaurante e em cafés da cidade ${ }^{10}$.

\footnotetext{
${ }^{5}$ CARNEIRO, Felipe. Os assassinos da inocência. Veja, edição 2409, ano 48, no 3, p. 61, 21 jan. 2015.

${ }^{6}$ WATKINS, Nathalia. Não vê quem não quer. Veja, edição 2414, ano 48, no 8, p. 65-65, 25 fev. 2015.

${ }^{7}$ Loc. cit.

${ }^{8}$ WATKINS, Nathalia. Os dois lados do terror. Veja, edição 2438, ano 48, n 32, p. 66-67, 12 ago. 2015.

${ }^{9}$ Loc. cit.

${ }^{10}$ TEIXEIRA, Duda. Uma sombra sobre a Europa. Veja, edição 2453, ano 48, nº 47, p. 70-77, 25 nov. 2015.
} 
A advogada Nina Shea, diretora do Centro de Liberdade Religiosa do Instituto Hudson, em Washington, afirma que alguns líderes muçulmanos no Irã consideram a ideia de genocídio completo dos cristãos ${ }^{11}$.

$$
* * *
$$

Três terroristas, na porta do aeroporto Atatürk em Istambul, tiraram fuzis das malas e começaram a atirar contra os guardas e vários civis. Depois, explodiram as bombas que traziam junto ao corpo matando mais de quarenta pessoas de dez nacionalidades ${ }^{12}$.

À beira da praia em Nice, sul da França, famílias com crianças, idosos e casais jovens assistiam aos fogos de artifício em comemoração à tomada da Bastilha, quando um caminhão branco dirigido por um terrorista islâmico, o imigrante tunisiano Mohamed Lahouaiej Bouhlel, de 31 anos, em ziguezague pela pista e pela calçada assassinou quase uma centena de pessoas ${ }^{13}$.

Abdel Malik Petitjean e Adel Kermiche, ambos de 19 anos e radicalizados pelas redes do Estado Islâmico na internet, invadiram uma igreja católica em Saint-Étienne-duRouvray, na França, e, armados com facas, degolaram o padre Jacques Hamel de 86 $\operatorname{anos}^{14}$.

Em setembro de 2016, uma bomba explodiu no bairro de Chelsea, em Nova Iorque, deixando 31 feridos. O suspeito foi identificado como Ahamad Khan Rahimi, radicalizado através da propaganda jihadista online ${ }^{15}$.

\footnotetext{
${ }^{11}$ Idem. Os mártires ao pé da cruz. Veja, edição 2472, ano 49, nº 14, p. 66-69, 6 abr. 2016.

${ }^{12}$ VEIGA, Edison. A tragédia anunciada na Turquia. Veja, edição 2485, ano 49, n²7, p. 64-65, 6 jul. 2016.

${ }^{13}$ WATKINS, Nathalia; COUTINHO, Leonardo. Um atropelo à humanidade. Veja, edição 2487, ano 49, nº 29, p. 60-63, 20 jul. 2016.

${ }^{14}$ NORTE, Diego Braga. Um terror sem fim. Veja, edição 2489, ano 49, no 31, p. 51, 3 ago. 2016.

15 TREVISAN, Cláudia; LEOPOLDO, Ricardo. Atropelamento em ciclovia tratado como ato terrorista mata ao menos oito em Nova York. O Estado de S. Paulo, Disponível em:
} 
No interior da arena Manchester, na Inglaterra, após o show da pop star americana Ariana Grande, jovens se encaminhavam para saída quando o inglês Salman Abedi, de 22 anos, foi até o hall localizado entre a arena, o estacionamento e a estação de trem e, com um detonador do tamanho de uma caneta, explodiu a bomba que estava na sua mochila, espalhando pedaços de pregos, porcas e parafusos por todos os lados: 22 pessoas que estavam em um semicírculo atrás do terrorista tiveram o corpo dilacerado e morreram; cerca de 150 pessoas ficaram feridas. Quase metade das vítimas tinha menos de 20 anos. O atentado reivindicado pelo Estado Islâmico ${ }^{16}$.

$* * *$

Foram encontradas trocas de mensagens tratando do planejamento de ataques terroristas entre os quatro brasileiros presos e condenados no âmbito da Operação Hash Tag da Polícia Feral brasileira durante os Jogos Olímpicos do Rio de Janeiro em 2016. Todos eram islamitas fundamentalistas ${ }^{17}$.

$$
* * *
$$

Em 22 de março do mesmo ano, o Estado Islâmico reivindicou o ataque terrorista que deixou dezenas de mortos e feridos no Aeroporto Internacional de Zaventem e na estação de metrô Maelbeek em Bruxelas, na Bélgica ${ }^{18}$.

$* * *$

Um atentado terrorista em Barcelona levou pânico à Espanha em 17 de agosto de 2017 após uma van atropelar vários pedestres em La Rambla, importante via no centro da

$<$ http://internacional.estadao.com.br/noticias/geral,policia-de-nova-york-investiga-tiroteio-emmanhattan,70002067872>. Acesso em 31 out. 2017.

${ }^{16}$ NUBLAT, Johanna. O massacre dos jovens. Veja, edição 2532, ano 50, nº 22, p. 78-81, 31 mai. 2017.

${ }^{17}$ BRONZATTO, Thiago. A Guantánamo tupiniquim. Veja, edição 2543, ano 50, no 33, p. 52-57, 16 ago. 2017.

18 ATENTADOS terroristas na Bélgica deixaram dezenas de mortos e feridos. G1. Disponível em: $<$ http://g1.globo.com/mundo/noticia/2016/03/aeroporto-de-bruxela-na-belgica-registra-explosoes.html>. Acesso em 30 nov. 2017. 
capital da Catalunha. Ao menos 13 pessoas morreram e mais de 100 ficaram feridas neste ataque, cuja autoria foi reivindicada pelo Estado Islâmico ${ }^{19}$.

$* * *$

"O atentado a bomba no metrô de Londres foi cometido pelo Estado Islâmico", anunciou a Amaq, o órgão de propaganda do grupo, em nota divulgada nas redes sociais. O ataque, que deixou 29 pessoas ferias em 15 de setembro de 2017, foi o quinto em seis meses no Reino Unido ${ }^{20}$.

$$
* * *
$$

Oito pessoas morreram e onze ficaram feridas quando um motorista em uma caminhonete avançou, em 31 de outubro de 2017, sobre ciclistas e pedestres no sul de Manhattan, Nova Iorque, no primeiro atentado terrorista com mortes na cidade desde o 11 de setembro de 2001. Segundo a polícia, o motorista gritou "Allahu akbar" quando saiu do veículo carregando duas armas ${ }^{21}$.

Ao fechar o jornal, sentimo-nos como se tivéssemos acabado de ler uma versão atualizada, ampliada e piorada do Livro do Apocalipse ${ }^{22}$.

19 ATENTADOS terroristas em Barcelona e Cambrils. El País. Disponível em: $<$ https://brasil.elpais.com/brasil/2017/08/17/internacional/1502987924_138296.html $>$. Acesso em 30 nov. 2017.

20 ESTADO Islâmico reivindica atentado terrorista em Londres. $O$ Globo. Disponível em: $<$ https://oglobo.globo.com/mundo/estado-islamico-reivindica-atentado-em-metro-de-londres-21827865>. Acesso em 30 nov. 2017.

21 TREVISAN, Cláudia; LEOPOLDO, Ricardo. Atropelamento em ciclovia tratado como ato terrorista mata ao menos oito em Nova York. Loc. cit.

${ }^{22}$ HARRIS, Sam. O fim da fé: religião, terrorismo e o futuro da razão. Trad. Pedro Serras Pereira. Lisboa: Tinta-da-China, 2007, p. 165. 


\section{CAPÍTULO PRIMEIRO}

\section{APRESENTAÇÃO DO PROBLEMA}

$\mathrm{Na}$ sombra que contrasta com o céu luzidio que deixa ver a cidade, uma sombra longínqua e que se punha mais ao alto, bem acima das concretas construções e da estrada entre os arvoredos, o que mais chamava a atenção era a expressão de terror: terror retratado no exato momento do horror experimentado, vivido no ápice do ato de monstruosidade, traduzido no mais absoluto e inquietante desespero desenganado, mas insistente, do menino que, boquiaberto e com seus olhos sob pálpebras cansadas e sobrancelhas apertadas a implorar por qualquer misericórdia e, ao mesmo tempo, a mirar o infinito - ou seria para nós? -, desnudo o torso, sentia, sobre sua nuca, a rigidez cúmplice de uma conhecida e enrugada mão esquerda que o imobilizava para que a direita, que beijara tantas vezes em sinal de respeito absoluto e, agora, revelava-se assassina, pudesse finalizar o que a faca afiada sugeria a poucos centímetros do seu pescoço. Mas, sobre esta mão muito velha, repousava uma outra jovem mão que, mesmo sem agressividade no toque, impedia, com eficácia, que a vida do garoto chegasse ao final. Era a mão direita de um anjo. Com seu rosto andrógino e sem registro de emoção alguma, enquanto apontava seu indicador esquerdo contra o agressor, fazia destacar cada uma das linhas de expressão do rosto daquele homem velho, calvo, cansado e tornado, naquele instante, também confuso e constrangido: afinal, tratava-se de um pai que, trajando suas melhores vestes, atentaria contra a vida de seu próprio e único filho enquanto era atentamente observado pela plácida figura de um bode, ironicamente mais humano, parecendo ter compaixão e não se importar, caso pudesse, fosse imolado no lugar do menino. 
$\mathrm{Na}$ literatura bíblica, conta-se que o próprio Deus pôs Abraão à prova e lhe ordenou tomar seu filho, o seu único filho Isaac, fruto de um milagre e a quem esse pai, embora duvidemos desse sentimento, tanto amava, e o oferecer em holocausto sobre uma montanha. Obediente, encontrada a montanha indicada por Deus, Abraão deixou o jumento e os dois servos e saiu sozinho com o menino. No caminho, pegou a lenha do holocausto e a colocou nas costas de Isaac, tendo ele próprio tomado nas mãos os instrumentos do sacrifício, o fogo e a faca. Sem que o menino desconfiasse da tarefa a ser cumprida, em nome de Deus, pelo pai, Abraão construiu o altar, colocou a lenha, depois amarrou seu filho e o colocou sobre o altar em cima da lenha. Abraão estendeu a mão e pegou a faca para imolar seu filho quando, imediatamente, um anjo o chamou do céu e ordenou que não lhe fizesse nenhum mal, pois tudo não passava de um teste de subordinação do Senhor Deus $^{23}$. O ser onisciente, afinal, tinha dúvidas - talvez seja por isso que alguns digam que Deus é brasileiro.

Completamente absortos frente à crueza da cena bíblica retratada por Caravaggio, passamos do assombro a um êxtase semelhante ao experimentado por Santa Teresa na arte de Bernini: diante do Sacrifício de Isaac, encontramos a alma de nosso trabalho e, assim, decidimos nos debruçar sobre a condição do fanático religioso no Direito civil, sujeito que já nos intrigara quando o encontramos, en passant, na leitura de Pontes de Miranda que, em alguma rápida e não repetida menção perdida em seu Tratado de Direito Privado, apontou para tese esposada em duas obras tedescas contemporâneas (1906), quais sejam, a de Hermann Werner ${ }^{24}$ e a de Theodor Braun ${ }^{25}$, a fim de afastá-lo das práticas confessionais se constatado o caso de mania religiosa ${ }^{26}$.

Perplexos com a retratação artística e com a respectiva narrativa bíblica, pensamos, então, nas incontáveis vítimas da fé: nos que passam por necessidades materiais diante da entrega dos bens em favor de um esperado milagre; nos que abandonam o certo tratamento médico para, depois frustrados, tentar a sorte que lhes resta nos precários hospitais e postos públicos de saúde; nas mulheres que, mesmo inseridas em um contexto democrático e de pretensa inviolabilidade dos direitos fundamentais, são subjugadas por seus maridos; nas

\footnotetext{
${ }^{23} \mathrm{Gn} 22,1-12$.

24 WERNER, Hermann. Kann das Christentum Geisteskrank machen? Askona: Schmidtz, 1906.

25 BRAUN, Theodor. Die religiöse Wahnbilgung. Tübingen: Mohr, 1906.

26 PONTES DE MIRANDA, Francisco Cavalcanti. Tratado de direito privado. Rio de Janeiro:
} Borsoi, 1955. t. 9, p. 316. 
crianças privadas de acesso à educação secular; nas meninas mutiladas em razão de preceitos arcaicos; nas jovens vítimas da lavagem cerebral praticada por religiosos fundamentalistas; nas vidas ceifadas pelos cada vez mais corriqueiros ataques terroristas; nos milhares de sonhos despedaçados daqueles que, incapazes de qualquer reação efetiva, perderam seus entes e amigos queridos nesses atentados; bem como pensamos em nós: nós que experimentamos a transição de uma "sociedade de risco" para uma "sociedade de medo".

Tal como Søren Kierkegaard, não conseguimos entender Abraão ${ }^{27}$. Nem Abraão e nem os fanáticos religiosos; e tudo quanto aprendemos deles nos tem deixado em estado de estupefação.

Por conseguinte, perguntamo-nos: poderíamos considerar, em algum grau, incapaz para o exercício pessoal de atos da vida civil, um sujeito religioso que, no gozo do fundamental direito à liberdade religiosa a lhe franquear, em princípio, comportamentos fundamentalistas, ultra ortodoxos, fanáticos, represente, em exclusiva decorrência de sua conduta confessional, potencial risco de danos, quaisquer que sejam, ou que, efetivamente, cause prejuízos, patrimoniais ou extrapatrimoniais - inclusive e simplesmente dando azo à colisão do seu direito com outro direito, seu ou de outrem -, para si, para seus dependentes ou para terceiros - e, possivelmente, até para uma numericamente considerável coletividade?

Uma vez que resta assegurada pelo Estado Democrático de Direito - Estado que deve lidar com a nova realidade do seu intrínseco componente populacional, ou seja, o multiculturalismo -, em cláusula constitucional pétrea, a inviolabilidade da liberdade de consciência e de crença e do livre exercício dos cultos religiosos ${ }^{28}$, a comentada conduta confessional fanática efetiva ou potencialmente danosa poderia sofrer limitações?

${ }^{27}$ KIERKEGAARD, Søren. Temor e tremor. Trad. Torrieri Guimarães. São Paulo: Hemus, 2008, p. 30.

28 Da Constituição da República Federativa do Brasil de 1988:

“Art. $5^{\circ}$ Todos são iguais perante a lei, sem distinção de qualquer natureza, garantindo-se aos brasileiros e aos estrangeiros residentes no País a inviolabilidade do direito à vida, à liberdade, à igualdade, à segurança e à propriedade, nos termos seguintes:

(...)

VI - é inviolável a liberdade de consciência e de crença, sendo assegurado o livre exercício dos cultos religiosos e garantida, na forma da lei, a proteção aos locais de culto e a suas liturgias;" 
Em suma: é possível cogitarmos, em virtude do descrito agir religioso, alguma incapacidade e, via de consequência, alguma restrição a esse sujeito fanático sem uma específica previsão legal, requisito imperioso para que se dê qualquer capitis deminutio?

Apesar do preceito constitucional da inviolabilidade da liberdade religiosa, três afirmativas são possíveis. E tal possibilidade se verifica após a atribuição de uma natureza jurídica ao fanatismo, após a perquirição de sua essência.

Propomo-nos à tarefa dessa identificação.

Forçoso e permanente o confronto de nosso tema com o direito fundamental da liberdade religiosa, constitucionalmente apresentado a partir da garantia de sua inviolabilidade, além de inescapáveis as considerações sobre o Estado laico, outro tema do Direito constitucional, e uma vez que confessamos ter sido uma tentativa de assassinato o estopim de nossos trabalhos, algo que deveria ser resolvido na seara do Direito penal, inevitável, assim, repetir a pergunta com a qual Christielle Landheer-Cieslak abre sua obra La religion devant les judges français et québécois de droit civil:

"Pourquoi le choix du droit civil?",29

Ora, direis, ouvimos estrelas e, certo, perdemos o senso. Mas vos diremos, no entanto, que o Direito civil é o campo mais adequado, num Estado Democrático de Direito e nos dias que correm, para encontrarmos instrumentos que, se não solucionam, têm grande potencial para evitar que os danos aconteçam.

É a própria Christielle Landheer-Cieslak quem oferece uma resposta exemplar quando constata que a adesão de um indivíduo a uma seita pode ser tão radical que, além do consequente rompimento com a família e com o ambiente socioprofissional em decorrência do fanatismo, também pode levar a situações dramáticas que coloquem em perigo a saúde ou a própria vida ${ }^{30}$.

Nossa pergunta pode, ainda, ser respondida de outra maneira: porque o direito fundamental da liberdade religiosa traz em si uma liberdade complexa, dado que é "a fronteira entre o individual e o coletivo"31.

${ }^{29}$ LANDHEER-CIESLAK, Christelle. La religion devant les juges français et québécois de droit civil. Brussels: Bruylant, 2008, p. 2.

${ }^{30}$ Ibidem, p. 7 (tradução nossa).

${ }^{31}$ Ibidem, p. 177 (tradução nossa). 
Por isso, a escolha do Direito civil.

Ademais, o Direito civil não vai servir de ferramenta apenas em hipóteses de fanatismos ou meras condutas antissociais, posto que ainda deverá lidar com questões mais comezinhas - nunca comezinhas para quem as vive, frisemos - como a de pais separados que professam confissões diferentes e não entram em consenso sobre a vida religiosa dos filhos ${ }^{32}$.

Apesar de nosso cuidado em abordar as principais e paradigmáticas implicações do exercício da liberdade religiosa, necessário reafirmarmos que nosso objeto, contudo, é a análise da capacidade civil do fanático religioso a partir da atribuição de uma natureza jurídica ao fanatismo, termo que, por razões práticas, sinonimizamos de fundamentalismo, extremismo, radicalismo, hiperreligiosidade e ultra ortodoxia.

Já quando mencionarmos "Religião", cumpre esclarecer que estaremos nos referindo a qualquer crença no sobrenatural, restando também sinonimizados, neste trabalho, religião, igrejas, cultos, seitas, confissões ou qualquer outro termo que se refira ao transcendental, ao sagrado.

Em homenagem à boa didática e tentando estabelecer uma ordem de oportunidade para apresentação dos argumentos, posto interessar que eles sejam ordenadamente aglutinados, nosso trabalho está dividido em seis capítulos.

Após este primeiro capítulo no qual apresentamos e circunscrevemos nosso problema, no segundo, depois das devidas considerações sobre a personalidade e a capacidade das pessoas naturais e, sequencialmente, as necessárias especificações e a importância do tratamento gradual das incapacidades - às quais incluiremos a chamada incapacidade natural (uma incapacidade acidental, passageira e pontual que pode aproveitar a qualquer pessoa de modo não permanente ou não persistente por qualquer causa, como, por exemplo, a embriaguez, o efeito de psicotrópicos ou de estupefacientes, uma doença súbita dos foros psicológico ou psiquiátrico, um delírio febril, um estado de pânico ou um trauma, bem como um estado hipnótico, sonâmbulo, de cansaço extremo, de euforia, de ira ou perante um acontecimento fasto) e sobre as quais lamentaremos o

32 Neste caso, por exemplo, é comum à Justiça francesa fazer essa escolha, ao passo que a quebequense se recusa a tanto em respeito ao direito da criança à livre escolha de sua religião. (Ibidem, p. 277) 
advento da Lei Brasileira de Inclusão da Pessoa com Deficiência (também chamada de Estatuto da Pessoa com Deficiência) e comemoraremos, apesar da timidez, as sequenciais alterações promovidas com a entrada em vigor do novo Código de Processo Civil brasileiro - proporemos uma teoria geral da capacidade civil que seja conforme ao Estado Democrático de Direito moderno que promova a previsibilidade, a segurança jurídica; uma teoria pautada no critério intelectivo, afastada de qualquer ranço de ordem moral (ainda identificado no caso do pródigo em nosso Código Civil) e na qual, em razão do atual estágio das ciências da mente (Psicologia, Psiquiatria e Neurociências), o fundamento das incapacidades de exercer certos atos da vida civil verifica-se na existência e no grau de alguma psicopatologia. A latere, consideraremos a positivação da incapacidade natural em razão de um determinado acontecimento excepcional e pessoal que faça com que o sujeito capaz aja manifestamente em prejuízo próprio, de modo que não o fizesse em condições ordinárias.

O capítulo subsequente vai equacionar direitos fundamentais e Direito civil. Partindo da influência que aqueles exercem sobre o comportamento das pessoas de Direito privado e de sua influência na aplicação e no desenvolvimento do Direito civil - que orienta a vida das pessoas de Direito privado -, concluiremos sobre o papel que este exerce, posto que deve exercê-lo, para a efetivação de modificações dos efeitos dos direitos fundamentais mesmo frente a inexistência de restrições constitucionalmente autorizadas, já que, nos conflitos de Direito privado, identificam-se, certamente, titulares de direitos fundamentais em cada um dos polos da relação.

No capítulo quarto, iniciamos a inserção da Religião no campo do Direito civil. Para que tenhamos êxito na mencionada inserção, mandatórias algumas breves considerações acerca da Religião, a qual identificaremos tão somente em essência e sem tecnicidade, dado que, como veremos, atributos técnicos não são possíveis na matéria, bem como sobre o Estado laico, cujas considerações são indispensáveis, pois o entendimento, ainda longe de ser pacífico, promove candência em qualquer debate, principalmente quando encerra uma população multicultural e, muitas vezes, incompatíveis com seus preceitos filosóficos e jurídicos, como é o caso, por exemplo, de islamitas e de judeus chassídicos. Isto posto, importará trazer à baila a discussão sobre a tolerância e a alvissareira expansão do laicismo para a esfera privada, muito embora o estado atual do Estado laico não seja muito promissor. Em seguida, como não poderia deixar de ser, inserimo-nos no debate sobre a 
liberdade religiosa: pugnando para que deva ser balanceada com os princípios da tolerância e do laicismo, inclusive dentro da casa do próprio religioso (ou do ateu), voltaremos alguma atenção para os mais emblemáticos casos problemáticos oriundos do seu exercício. Estabelecidas tais bases, passaremos a analisar a aplicação e o desenvolvimento do Direito civil no âmbito de um Estado laico que garante a inviolabilidade da liberdade religiosa em um contexto populacional multicultural a fim de apontarmos, justificando-o como ferramenta mais apta para lidar com a problemática religiosa em nossos dias, especialmente quando trata da capacidade da pessoa natural, do poder familiar, dos deveres conjugais e para com a prole, bem como quando dispõe sobre casos de abuso do direito e coação moral. Aproveitaremos a temática para trazer a lume um debate atual sobre a "relação de consumo religiosa".

O quinto capítulo tratará, a partir das conclusões dos temas abordados anteriormente, do objeto de nossa tese: da condição do fanático religioso no Direito civil.

Inicialmente, convém apresentarmos uma breve evolução da história da Psiquiatria para o reconhecimento do atual estágio das ciências da mente, como já mencionamos, Psicologia, Psiquiatria e Neurociências, e legitimá-las como instrumentos fundamentais para as nossas conclusões, pois, dados o acúmulo das pesquisas e a evolução das tecnologias, permitiram e permitem segura identificação dos efeitos da Religião sobre o comportamento e a saúde mental e física das pessoas naturais, isoladas ou coletivamente, bem como o diagnóstico do fanatismo religioso como transtorno ou sintoma de alguns transtornos mentais, enfermidades que encontram terreno fértil para manifestação ou agravamento nessa forma bastante fervorosa de vivência confessional. Encontrada, assim, a natureza jurídica do fanatismo, é possível o enquadramento legal do fanático religioso como sujeito relativamente incapaz, inapto, dessa maneira, para, por si só, praticar diferenciados atos da vida civil, o que garante a efetividade do princípio da precaução inserido pela modernidade no Direito civil, da saúde, da segurança públicas e da proteção dos direitos da criança e do adolescente. Em suma, o fanatismo é um estado pessoal de alerta e, portanto, passível de promover danos, os mais variados, para o próprio fanático, para a sua família e para a sociedade, razão pela qual clama pelo tratamento jurídico específico conforme a extensão da incapacidade.

Acrescentamos, neste capítulo principal, algumas considerações acerca de possíveis óbices à nossa conclusão trazidos pelo já oportunamente criticado Estatuto da Pessoa com 
Deficiência, bem como sobre as contribuições jurisprudenciais dos tribunais quebequenses e franceses, únicos a tratar de alguma sobre o tema que escolhemos.

Em acréscimo, entendemos conveniente tecer alguns comentários acerca de duas outras espécies de fanatismo muito familiares, quais sejam, o político e o futebolístico.

Por derradeiro, no último capítulo, traremos uma compilação de nossas conclusões e uma proposta de revisão legislativa.

Percorrido nosso plano de trabalho em suas especificidades, convém destacar a sempre presente busca, em cada tópico controverso, de um ponto de equilíbrio entre direitos e garantias igualmente fundamentais, mas opostos, em princípio, em algumas situações. Para tanto, imperiosa a sopesagem dos fundamentos de cada um deles frente à sempre presumida legitimidade do discurso e do agir religioso, pois não é, e nem poderia ser, nosso objetivo desrespeitar o direito fundamental da liberdade religiosa e nem apequenar seus acólitos e fiéis. A conquista histórica que tal garantia constitucional representa é determinante para que o jurista não caia na tentação de se satisfazer apenas e exclusivamente com a lógica de um discurso dawkiniano ou de somente considerar, na esteira de José Saramago, que, "além de tão filho da puta como o senhor, abraão era um refinado mentiroso", pois, naquela passagem bíblica que nos serviu de matéria-prima, “[o] lógico, o natural, o simplesmente humano seria que abraão tivesse mandado o senhor à merda, mas não foi assim." ${ }^{\text {33 }}$ Logo, tal como Christopher Hitchens, muito embora também acreditemos que os dilemas éticos são mais bem tratados nas obras de Shakespeare e de Dostoievski do que nos livros sagrados, não nos baseamos unicamente na ciência e na razão, fatores necessários mas não suficientes ${ }^{34}$ para esta empresa.

De qualquer modo, Isaac não pode ser sacrificado no Estado Democrático de Direito. E, para que não o seja, esse mesmo Estado não pode continuar a ignorar a condição de Abraão.

Devemos estar atentos, pois a idade das trevas não acabou por falta de trevas.

33 SARAMAGO, José. Caim. São Paulo: Companhia das Letras, 2009, p. 79.

34 HITCHENS, Christopher. Deus não é grande: como a religião envenena tudo. Trad. George Schlesinger. São Paulo: Globo Livros, 2016, p. 18-19. 


\section{CAPÍTULO SEXTO}

\section{CONCLUSÕES E PROPOSTA DE REVISÃO LEGAL}

$\mathrm{Na}$ esteira da confissão de Ulrich Beck, como cientistas, trazemos no sangue o idioma do secularismo, acreditando na força redentora do iluminismo sociológico e jurídico $^{646}$.

Mas, que reste claro, com isso não queremos dizer que vivemos "na fronteira entre um passado exaurido e um futuro sem ilusões e esnobismos, onde a única realidade resida nas certezas da máquina de lavar e do forno de micro ondas." 647

${ }^{646}$ BECK, Ulrich. O Deus de cada um, p. 7.

Mas a doutrina jurídica ainda está permeada de autores sem secularismo no sangue, razão que nos incentivou a levar adiante o presente trabalho. Como exemplo, o Professor da Faculdade de Direito da Universidade de Roma Francesco D’Agostino, que, textualmente, acusa o iluminismo dos grandes males dos últimos séculos: o liberalismo do sistema financeiro neste, o fascismo, o nazismo e o marxismo-leninismo no anterior e, no XIX, o nacionalismo e o colonialismo. Tudo porque os iluministas subtraíram de Deus a fonte legítima da autoridade política. (D’AGOSTINO, Francesco. Diritto e religione, p. 36)

Como explicar, então, que, após derrubada do xá do Irã, em 1978, e a tomada de todos os poderes pelo aiatolá Khomeini, inaugurou-se um real fascismo muçulmano, observa Michel Onfray, ainda instalado um quarto de século mais tarde, com a bênção do Ocidente silencioso e esquecido? (ONFRAY, Michel. Tratado de ateologia, p. 177)

A resposta de D’Agostino, ponderado tivesse esse fato, pode ser encontrada no final de seu livro, quando, ao iniciar as Cruzadas do pensamento, afirma, sem ruborescer, que: "A religiosidade católica, por fim, constitui a condição de possibilidade fundamental (fundamental porque espiritual) para a mundialização." (Ibidem, p. 82 - tradução nossa)

A esse pensamento, gostaríamos de contrapor o pensamento de Tobias Barreto: "É preciso reconhecer que a audácia do escritor leviano não é menos perigosa que a do leitor insensato e sem critério para dar às palavras e às ideias seu verdadeiro valor.

A crítica religiosa é um dos poderes do século cuja atmosfera moral está impregnada da poeira a que ela tem reduzido as antigualhas caducas; sua influência é inevitável a qualquer espírito ambicioso de luz; os grandes homens que se hão colocado à frente do movimento são de uma enorme estatura, e projetam até nós suas sombras gigantescas." (BARRETO, Tobias. Crítica de religião. Rio de Janeiro: Solomon; Sergipe: Editora Diário Oficial, 2012, p. 71)

${ }^{647}$ BALLARD, J. G.. O reino do amanhã, p. 349. 
Seculares que somos, importa reconhecer que, afirmando não a nossa tolerância, mas o nosso mais profundo e genuíno respeito a todas as crenças e crentes tolerantes, tanto as posições que sentenciaram a inevitável morte do sagrado como as que cantam a involução do processo, conforme sentencia Fernando Catroga, pecam por excesso, pois se esquecem que a secularização não é fenômeno antirreligioso, mas simples afirmação da autonomia do século $^{648}$. Século que evolui.

Muito embora o direito fundamental de exercício da liberdade religiosa não tenha sido o objeto do presente trabalho, mas a autonomia da vontade de um portador de transtorno mental manifestado ou agravado pela hiperreligiosidade e seu potencial ofensivo ou efetivos prejuízos de qualquer natureza para si próprio ou para terceiros, em especial os membros de sua família, uma autonomia da vontade deficiente que deturpa a maneira de externar e vivenciar tal liberdade em harmonia com o Ordenamento, que deve ser, nestes dias em que os choques normativos se multiplicam em progressão geométrica, encarado como Sistema ${ }^{649}$, e razão pela qual o Direito civil deve oferecer o manto protetor que reserva aos incapazes, nosso tema não poderia ser indiferente a esse direito fundamental, especialmente em razão da sua habitual e quase sempre esperada colisão com outros tantos direitos.

Assim é que, além de refletir sobre a essência da Religião, analisamos as vertentes doutrinárias a fim de tomar partido sobre uma via de interpretação e aplicação do direito humano que nos acompanhou em cada etapa de nossa análise dentro de um Estado Democrático de Direito.

Coube também, ex officio, extrair entendimento sobre o que vem a ser um Estado laico e quais as implicações do laicismo - noções abaladas pelo progressismo que nos entrega a condição medíocre de uma sociedade semissecular na qual a Religião tem se sobressaído e controlado o Estado - num contexto de universalização dos direitos humanos fundamentais e de populações multiculturais, sob a ótica, é claro, da razoabilidade, da lógica e da sua aplicabilidade frente as colisões dos direitos fundamentais principalmente, conforme já salientamos insistentemente, do direito fundamental da liberdade religiosa - com outros direitos de mesma magnitude ou, da mesma forma, outros

${ }^{648}$ CATROGA, Fernando. Entre deuses e Césares, p. 453.

${ }^{649}$ E Francisco Amaral é categórico ao salientar que "Sistema não é sinônimo de ordenamento, embora alguns juristas defendam a sinonímia.” (AMARAL, Francisco. Direito civil..., p. 39) 
que, embora não apresentem, nominalmente, a mesma grandeza, não deixam de ser corolários daqueles astros, bem como as respectivas consequências para a aplicação e o desenvolvimento do Direito civil que, em tais situações, poderá operar como agente de modificação dos seus efeitos mesmo que as restrições, necessárias para a harmonização do Sistema jurídico, não estejam expressamente autorizadas pela Constituição, devendo, para isso, atender aos critérios de: (i) aptidão; (ii) indispensabilidade; (iii) proporcionalidade; (iv) razoabilidade; e $(v)$ determinabilidade.

O Estado laico ideal, obviamente, deve ter uma postura laica e promover o laicismo, mas não o ateísmo, muito embora se alimente, posto inexistir opção alternativa e ser um fruto dele, do secularismo, que é ateu até que a Ciência prove o contrário, como fundamento para a promoção do conhecimento, principalmente na área da educação pública, bem como para a produção e aplicação das leis. A tal postura, a modernidade exige que o laicismo se desenvolva mais na esfera privada do que na pública, impondo-se ao Estado que se adeque quanto ao fenômeno religioso, deixando em parte o predomínio do modelo institucional e passando a responder às demandas mais concretas que aparecem na sociedade num contexto em que as confissões restam obrigadas a renunciar à pretensão de monopolizar a interpretação e a configuração da vida.

Para a empreita, a tônica deve ser a tolerância para o Estado, para a Religião e para qualquer pessoa no exercício do direito fundamental da liberdade religiosa, mesmo que na privacidade do lar, uma vez que as portas das casas não podem se fechar para os direitos fundamentais, seja no que toca, por exemplo, à igualdade entre homens e mulheres, seja na proteção da criança e do adolescente, seja na garantia da dignidade humana a quem quer que seja.

Não se pode dar imunidade, como faz o Direito tributário condenado que foi pelo constitucional, ao dever de tolerar nem se abrir exceções ao direito de ser tolerado.

A tolerância não é um sentimento - e nem pode ser. Ela é ação e, se algum sentimento existe, é o de sacrifício, posto que, antes de agir de maneira tolerante, existe uma escolha, a escolha de negar um elemento da vontade após o cálculo da recompensa; se o intolerante deve ser tolerado de qualquer forma, o sistema jurídico rui.

A intolerância evidencia, assim, o fenômeno do fanatismo religioso, problema que, frente aos vultosos e significativos avanços das ciências, não pode mais ser analisado 
somente através de conjecturas ou sentenciado com o molieresco diagnóstico do mutismo de Lucinde em Le médecin malgré lui: "A filha de Géronte não fala porque está muda", diria Sganarelle ${ }^{650}$.

Tais observações talares à doutrina constitucional, repetimos, não poderiam ser olvidadas nestas conclusões, pois nosso tema de estudo, apesar de se baralhar, posto que indissociáveis em suas externalidades, com a defesa dos direitos de terceiros e do próprio sujeito no exercício do direito fundamental da liberdade religiosa, com ele não se confunde. Nosso objeto é anterior tanto à defesa descrita quanto ao próprio agir religioso: é a própria pessoa natural, cuja plena capacidade, por experimentar a Religião de maneira fanática, é posta em xeque.

Apesar da vasta bibliografia e de julgados, principalmente europeus, sobre o exercício da liberdade religiosa, cumpre repisar que toda essa informação, levantada e estudada para a redação da tese que apresentamos, não trata da questão religiosa no que toca à autonomia da vontade e sobre as implicações na capacidade do sujeito religioso. Pressupondo sempre plena capacidade jurídica, partem diretamente para o fato decorrente do agir religioso ou para a defesa de direitos do próprio religioso ou de terceiro.

Com a exceção do citado caso judicial quebequense, nem doutrina e nem jurisprudência, nacional ou alienígena, tratam da pessoa do fanático religioso no que toca a sua capacidade. Inexiste, em outros dizeres, substrato para estudo de fonte, comparado ou não, e para uma proposta de resposta mais preventiva do que corretiva (embora também o seja), longa e duradora (mas que também pode ter efeitos imediatos em caso de tutela antecipada) ao fanatismo religioso.

Insistimos: os casos paradigmáticos de embate entre o exercício do direito da liberdade religiosa e outros direitos próprios ou de terceiros, casos mencionados em suas linhas gerais por não coincidirem com o nosso objeto (embora dele sejam provavelmente derivados), foram por nós utilizados como hipóteses de alerta, bem como reputados elementos para o pedido de constituição da incapacidade relativa do fanático religioso, pois, independentemente das discussões e julgados sobre a extensão do direito fundamental

650 MOLIÈRE. Le médecin malgré lui. Paris, 1666. Disponível em: $<$ http://www.toutmoliere.net/IMG/pdf/medecin_malgre_lui.pdf > . Acesso em: 11 nov. 2017. 
da liberdade religiosa, a presença de um comportamento inadequado é sintomática e facilita a detecção de algum transtorno mental.

Apropriamo-nos, assim, com as modificações e especificidades que nossos tempos requerem, de valiosa e, em certo aspecto ainda atual, queixa de Nina Rodrigues: a perícia e os avanços da Neurociência na seara das capacidades não podem ser um simulacro sem valor, pois, da maneira como ideologizada pela novel legislação, o Direito mais se arrisca a comprometer a vida, a honra e a liberdade do cidadão, do que a concorrer para sua proteção $^{651}$.

Se a maioria dos estudos científicos envolvendo experiências religiosas comprovam uma relação positiva entre Religião e saúde mental, faz-se fundamental a distinção entre religiosidade $(i)$ intrínseca, ou seja, em sua identificação positiva quando inversamente proporcional com dogmatismo, pensamento irracional e insegurança, e (ii) extrínseca, negativamente valorada posto que correlacionada positivamente com dogmatismo, pensamento irracional, sentimentos de impotência, medo da morte e intolerância. Por sua vez, se a religiosidade extrínseca se correlaciona com a ausência de saúde mental, ao Direito não pode interessar que tais esclarecimentos científicos sejam remetidos a um índex, razão pela qual não somente as doutrinas constitucionalistas acerca do direito fundamental da liberdade religiosa merecem absoluta revisão, mas também e especialmente a doutrina da capacidade civil, uma vez que a sua verificação clínica aponta para a ausência ou deturpação da autonomia da vontade do sujeito religioso, que pode representar um ponto de ruptura no escopo da pacificação social, sem o qual o Direito é imprestável.

De fato, a partir das evoluções científicas apontadas, se não podemos afirmar que o fanatismo religioso é uma entidade nosológica autônoma, havemos de concluir que ele é um sintoma de algum transtorno mental, que pode, apesar de outros sintomas ou ausência de demais, ser motivo único para que se conclua sobre a inaptidão do indivíduo para, por si só, praticar diferenciados atos da vida civil, não restando outra opção ao Direito, em especial ao Direito civil, a não ser a de encarar o indivíduo fanático religioso como um sujeito relativamente incapaz.

651 RODRIGUES, Raimundo Nina. O Alienado no direito civil brasileiro. 3. ed. São Paulo: Companhia Editora Nacional, 1939, p. 222. 
Para tanto, principalmente após a entrada em vigor da lei nº 13.146/2015 (Estatuto da Pessoa com Deficiência) em janeiro de 2016, devemos altercar, antes de tratar do fanatismo religioso como agente promotor da incapacidade relativa da pessoa natural em decorrência de transtorno mental, uma teoria geral da capacidade civil que confira previsibilidade para a constituição das incapacidades, ou seja, segurança jurídica à matéria que envolve quiçá o bem mais preciso do indivíduo: a liberdade.

Se, por um lado, é certo que o Estatuto da Pessoa com Deficiência retirou todos os portadores de transtornos mentais das enumerações incapacitantes, absoluta ou relativamente, tornando-os juridicamente, assim, plenamente capazes - inclusive quanto aos ditos direitos sexuais e reprodutivos e os direitos de votar e ser votado - e os deixou, em virtude de uma ideologia, alijados do manto protetor antes proporcionado pelo Código Civil, bem como alijou a interdição absoluta e relegou a curatela para indefinidos casos excepcionais, não se pode deixar de considerar, por outro, que o superveniente Código de Processo Civil restaurou a interdição sem a anuência do interditando, que deverá ser graduada caso a caso conforme a gravidade do transtorno mental.

De qualquer forma, intocado deve restar o princípio de outrora e de hoje: a capacidade é a regra; a incapacidade, exceção.

Não definindo a lei o que é a capacidade e nem a ela indicando requisitos, deve partir, pois, do princípio de que todos são capazes e estabelecer os casos de incapacidade geral, relativa e, acrescentamos, natural, sempre conforme os vícios que incidem na própria vontade, na sua formação.

Frente aos recursos científicos de que o operador do Direito dispõe nos dias que correm, eventual falta da consciência pressuposta pela vontade é perfeitamente identificável quando se está diante de um transtorno mental. Por isso, ao passo que a essência de qualquer incapacidade para o exercício dos atos da vida civil deve residir na situação mental da pessoa, as consequências privativas dessa incapacidade devem sempre se dar em virtude e no grau de alguma psicopatologia, bem como, se considerarmos uma incapacidade natural, em razão de um determinado acontecimento excepcional e pessoal que faça com que o agente aja, naquele momento, prejudicando-se de modo que não o fizesse em condições ordinárias. 
Bom alvitre, acrescentamos, inexistam categorias de natureza moral de incapacidade, mesmo que relativa, como é o caso do pródigo, no qual a natureza jurídica da prodigalidade, ainda em nosso Código Civil, está em desencontro com a prodigalidade científica atual, visto que pode ser identificada como sintoma de alguns transtornos mentais.

Mas, a despeito da destruição da doutrina da capacidade civil pelo Estatuto da Pessoa com Deficiência, o tratamento do fanático ainda é possível mesmo sem a reforma da criticada lei: o fundamentalismo religioso pode ensejar curatela nos antigos moldes dos relativamente incapazes por razões mentais graças, como assinalamos acima, à entrada em vigor do atual Código de Processo Civil ou, não fosse ele, de acordo com a natureza moral de uma interdição para efeitos meramente patrimoniais quando aproximado à prodigalidade, bem como se considerarmos a passagem da figura da incapacidade natural com o advento do novel inciso III no artigo $4^{\mathrm{o}}$ do Código Civil - estas duas hipóteses sempre subsistirão mesmo quando a análise científica de identificação de transtornos mentais se revelar inconclusiva (se conclusiva, repetimos, a aplicação das disposições da mencionada codificação processual).

Sob qualquer ótica, o Direito civil é a ferramenta mais apta e menos traumática de que dispõe o Direito para lidar com o fenômeno do fanatismo religioso, um estado pessoal de alerta e, portanto, passível de danos, os mais variados, para a sua família, para a sociedade e para o próprio fanático, convindo, ademais, salientar que, na falta da plena capacidade do fanático religioso, quaisquer hipóteses de privações aplicáveis pelo magistrado devem ser bem delimitadas na sentença a partir da indispensável ponderação de todas as circunstâncias em concreto.

Assim sendo, porque o novo Código de Processo Civil permite, novamente, o tratamento gradativo de enfermidades mentais para a determinação da necessidade e da extensão da curatela, uma revisão legal ideal é bastante simples e vai no sentido de que apenas sejam excluídos os "portadores de deficiência mental e intelectual" do corpo do Estatuto da Pessoa com Deficiência.

Independentemente de voltarem a ser tratados, no que se refere à capacidade das pessoas naturais, no corpo do Código Civil, a exclusão sugerida é bastante a fim de 
proporcionar estabilidade e segurança jurídica, fatores, como dissemos à exaustão, essenciais ao Direito.

Isto posto, dados os entendimentos pertinentes sobre o Estado Democrático de Direito, que é necessariamente laico e que tem o dever de harmonizar e pacificar a sociedade no hodierno contexto multicultural, bem como sobre a imprescindibilidade de restrições no exercício do direito fundamental da liberdade religiosa, se, no caso de eventual embate intransponível entre secularismo e religiosidade, norteados e subjugados que estamos pelo pilar da vida humana com dignidade num mundo no qual se sobrevive "graças” à ciência e se morre pela fé, já não restaria dúvida sobre qual caminho tomar, o que dizer, então, quando a Ciência é certeira, clara e inconteste em comprovar a correlação entre fanatismos religiosos e transtornos mentais?

Dar de ombros às revelações científicas sobre o fanatismo religioso equivale a não dar ouvidos, como era bastante comum há décadas atrás, a uma criança ao denunciar o abuso sexual por ela sofrido nas mãos de um sacerdote, visto que estariam fantasiando ou não compreenderam a situação narrada. É negar a realidade e perpetuar o horror por acreditar que o padre não peca.

A curatela do fanático religioso, concluímos, faz-se premente frente ao avanço em escala mundial dos fundamentalismos religiosos que, sem contar os ataques terroristas que já ceifaram centenas de vidas inocentes nas democracias ocidentais, insistem em solapar a harmonia e o gozo do conjunto de direitos humanos fundamentais.

Bem observa Giuseppe Capograssi: "Seria preferível que não fossem necessárias catástrofes para entender, mas o homem é feito de modo a precisar da terrível pedagogia da história. (E a dificuldade é que, para entender, esta é condição necessária, mas não suficiente).,

Quantas outras monstruosidades em nome da fé serão necessárias para que o problema do fanatismo religioso seja encarado sem as demagogias que cingem o direito fundamental da liberdade religiosa?

${ }^{652}$ CAPOGRASSI, Giuseppe. La vita etica, p. 481. (Tradução nossa) 


\section{NOTAS FINAIS}

Apesar de pouca ou nenhuma comunhão com sua prostração política e de estranhar o ateísmo dos fanáticos da, conforme a lapidar expressão de significado talar cunhada por Raymond Aron, religião secular, gostaríamos de encerrar este trabalho com a sentença de José Saramago:

Ao leitor crente (de qualquer crença...) que tenha conseguido suportar a repugnância que estas palavras provavelmente lhe inspiraram, não peço que se passe ao ateísmo de quem as escreveu. Simplesmente lhe rogo que compreenda, pelo sentimento de não poder ser pela razão, que, se há Deus, há um só Deus, e que, na sua relação com ele, o que menos importa é o nome que lhe ensinaram a dar. ${ }^{653}$

"Gostaríamos" porque não podemos, pois, se tudo parte de Deus, tudo tem a sua inquestionável e indelével lógica divina e, portanto, a diversidade do todo não pode ser subjugada por uma parte dessa mesma criação que é o ser humano.

Pois, se o mistério de Deus é insondável, peca quem ousa supor conhecê-lo no todo e julga todo o esplendor de sua suposta criação, restando razão a Kant quando afirma que "tudo o que o homem, além de uma boa conduta, imagina poder ainda fazer para se tornar

${ }^{653}$ SARAMAGO, José. O fator Deus. Folha Online. Disponível em: $<$ http://www1.folha.uol.com.br/folha/mundo/ult94u29519.shtml>. Acesso em 19 set. 2017.

Quanto ao "ateísmo de quem as escreveu" aplicado à presente tese, pode ser que reste razão a Millôr Fernandes e sejamos somente ateus enquanto estivermos muito bem de saúde. (FERNANDES, Millôr. Millôr definitivo, p. 40) 
agradável a Deus é simples ilusão religiosa e pseudo-serviço de Deus ${ }^{\text {"654 }}$. Desse modo, quando ele se afasta, ainda que só no mínimo, da máxima anteriormente mencionada, o pseudo-serviço de Deus não tem doravante limites, porque, para além dela, tudo é arbitrário $^{655}$.

A convicção de alguém em ser capaz de poder distinguir os efeitos da graça dos da natureza, ou até de conseguir em si os produzir, é manifesto fanatismo, já que, ainda na esteira de Kant, pretender percepcionar em si influências celestes é um modo de loucura em que, inclusive, pode haver método, mas que continua sempre a ser uma automistificação prejudicial à Religião ${ }^{656}$.

Então, se todo o mal das perseguições religiosas e das castrações nos mais variados sentidos se dão em nome de Deus, bem como se aqueles que o fazem alegam divino mandato, Deus é o pecado - e não existe razão que se perceba capaz impedir que o fanático religioso, atendendo aos desígnios do seu Deus em qualquer lugar e tempo, atente contra os seus próprios direitos fundamentais e os de terceiros.

Disso decorre a necessidade de uma resposta eficaz do Direito, ainda mais quando, disponíveis e acessíveis os instrumentos oferecidos pelas ciências da mente, o fanatismo desvela a incapacidade do sujeito e já são vigentes as medidas respectivas protetivas.

Por derradeiro, mesmo certos de nossas conclusões absolutamente respeitosas e acolhedoras de todas as manifestações religiosas também respeitosas e acolhedoras - ou, no mínimo, suficientemente tolerantes - com as demais crenças e todas as pessoas, se, ainda assim, o mesmo leitor crente que conseguiu suportar a nossa repugnante teoria estiver ofendido, sentindo-se insultado, perseguido ou caluniado por causa do Senhor,

${ }^{654}$ KANT, Immanuel. A religião nos limites da simples razão. Trad. Artur Morão. Lisboa: Edições 70, 2008, p. 172.

Nesse sentido, David Hume: "É certo que, em toda religião, por mais sublime que seja a definição verbal que ela ofereça de sua divindade, muitos adeptos, talvez a maioria, procurarão, não obstante, obter o favor divino, não por suas virtudes nem por seus bons costumes, únicas coisas que podem ser agradáveis a um ser perfeito, senão por práticas frívolas, por um zelo imoderado, por êxtases violentos ou pela crença em opiniões misteriosas e absurdas.” (HUME, David. História natural da religião, p. 115)

Tobias Barreto, nessa esteira de pensamento, faz observação que também merece destaque: “O certo é que ou Deus é imanente ao universo e, nesse caso, a teologia, ciência universal, é impossível, ou está acima da natureza e supera todo o criado, então de que modo será percebido, perguntamos, por nossa faculdade, o que está acima da natureza e, ainda, acima das mesmas faculdades que são naturais?” (BARRETO, Tobias. Crítica de religião, p. 67)

${ }^{655}$ Ibidem, p. 174.

${ }^{656}$ Ibidem, p. 176. 
sugerimos que se sinta confortado, homenageado, alegre e contente, posto ser, conforme o Evangelho de Mateus, um bem-aventurado e porque será grande a sua recompensa no céu ${ }^{657}$.

Em verdade vos dizemos, a vós que temeis o Senhor Deus, o homem ou ambos:

"Videte, vigilate; nescitis enim, quando tempus sit." 658

${ }^{657}$ Mt 5,11-12.

${ }^{658} \mathrm{Mc} 13,33$. 


\section{BIBLIOGRAFIA}

ALLPORT, Gordon W. Desenvolvimento da personalidade: considerações básicas para uma psicologia da personalidade. 2. ed. Trad. Helmuth Alfredo Simon. São Paulo: Herder, 1966.

ALMEIDA, Alexander Moreira de. Fenomenologia das experiências mediúnicas, perfil e psicopatologia de médiuns espíritas. Tese (Doutorado em Psiquiatria) - Faculdade de Medicina, Universidade de São Paulo, São Paulo, 2004.

AMARAL, Francisco. Direito civil: introdução. 3. ed. Rio de Janeiro: Renovar, 2000.

AMBALU, Shulamit et al. O livro das religiões. Trad. Bruno Alexander. São Paulo: Globo Livros, 2014.

ARBEX, Daniela. Holocausto brasileiro. São Paulo: Geração Editorial, 2013.

ARENDT, Hannah, Eichmann em Jerusalém: um relato sobre a banalidade do mal. Trad. José Rubens Siqueira. São Paulo: Companhia das Letras, 1999. 
ARGYLE, Michael. Conducta religiosa. Trad. Máximo Siminovich. Buenos Aires: Paidós, 1966.

ARISTÓTELES. Ética a Nicômaco. Trad. Edson Bini. Bauru: Edipro, 2002.

ARMSTRONG, Karen. O Islã. Trad. Anna Olga de Barros Barreto. Rio de Janeiro: Objetiva, 2001.

ARON, Raymond. O ópio dos intelectuais. Trad. Jorge Bastos. São Paulo: Três Estrelas, 2016.

ATRAN, Scott. Genesis of suicide terrorism. Science-American Association for the Advancement of Science, v. 299, p. 1534-1539, mar. 2003.

ATWOOD, Margaret. O conto da aia. Trad. Ana Deiró. Rio de Janeiro: Rocco, 2017.

AZARI, Nina P. et al. Short Communication: Neural correlates of religious experience. European Journal of Neuroscience-Federation of European Neuroscience Societies, v. 13, p. 1649-1652, 2001.

AZEVEDO, Antônio Junqueira de. Ciência do direito, negócio jurídico e ideologia. In: FRANCESCO, José Roberto Pacheco di. Estudos em homenagem ao Professor Silvio Rodrigues. São Paulo: saraiva, 1989, p. 1-22.

Caracterização jurídica da dignidade da pessoa humana. Revista dos Tribunais, São Paulo, ano 91, v. 797, p.11-26, mar. 2002.

AZEVEDO, Damião Alves de Azevedo. Partidos políticos, organizações religiosas e instituições confessionais: sua adequação ao novo Código Civil e a continuidade de convênios públicos. Revista CEJ. Brasília, n. 32, p. 101-107, jan./mar. 2006.

BALLARD, J. G.. O reino do amanhã. Trad. José Geraldo Couto. São Paulo: Companhia das Letras, 2009. 
BARRETO, Tobias. Crítica de religião. Rio de Janeiro: Solomon; Sergipe: Editora Diário Oficial, 2012 (Obras Completas de Tobias Barreto; V. 10).

BARROS, Daniel Martins de. Machado de Assis: a loucura e as leis - direito, psiquiatria e sociedade em doze contos machadianos. São Paulo: Brasiliense, 2010.

. O que é psiquiatria forense. São Paulo: Brasiliense, 2008.

BARROSO, Luís Roberto. Legitimidade de recusa de transfusão de sangue por Testemunhas de Jeová. Dignidade humana, liberdade religiosa e escolhas existenciais. In: VILLAÇA AZEVEDO, Álvaro; LIGIERA, Wilson Ricardo (Coord.). Direitos do paciente. São Paulo: Saraiva, 2012. p. 343-382.

BASTOS, Celso Ribeiro. Direito de recusa de pacientes, de seus familiares ou dependentes, às transfusões de sangue, por razões científicas e convicções religiosas. Parecer. São Paulo, 2000. Disponível em: $<$ http://www2.mp.pr.gov.br/cpca/telas/ca_igualdade_31_2_1_1.php $>$. Acesso em: 3 out. 2014.

BAUMAN, Zygmunt. O mal-estar da pós-modernidade. Trad. Mauro Gama; Cláudia Martinelli. Rio de Janeiro: Zahar, 1998.

BECK, Ulrich. O Deus de cada um. Trad. Celeste Aida Galeão; Johannes Augel. Rio de Janeiro: Tempo Brasileiro, 2016.

BENTLEY JR., G. E.. The stranger from Paradise. New Haven: Yale University Press, 2003

BERGER, Benjamin. The limits of belief: freedom of religion, secularism, and the liberal State. Canadian Journal of Law and societi, v. 17, nº 1, 2002, p. 39-68. 
BERGERET, Jean. Prélude à une étude psychanalytique de la croyance. Revue Française de Psychanalise de Paris: Croyances, 3, t. LXI, p. 877-896, jul.-set. 1997.

BIANCA, C. Massimo. Istituizioni di diritto privato. Milano: Giuffrè, 2016.

BOBBIO, Norberto. A era dos direitos. Trad. Nelson Coutinho. Rio de Janeiro: Elsevier, 2004.

- Teoria geral da política: a filosofia política e as lições dos clássicos. Org. Michelangelo Bovero. Trad. Daniela Beccaccia Versiani. Rio de Janeiro: Campus, 2000.

BOURDIEU, Pierre. A produção da crença: contribuição para uma economia dos bens simbólicos. 3. ed. Trad. Maria da Graça Jacintho Setton. Porto Alegre: Zouk, 2014.

. O poder simbólico. Trad. Fernando Tomaz. 14. ed. Rio de Janeiro: Bertrand Brasil, 2010.

. A economia das trocas simbólicas. Trad. Sergio Miceli. São Paulo: Perspectiva, 1999.

Razões práticas: sobre a teoria da ação. Trad. Mariza Correa. Campinas: Papirus, 1996.

BOURGUIGNON, Erika (Ed.). Religion, altered states of consciousness and social change. Columbus: Ohio Satate University Press, 1973.

BRAGANÇA, Ubirajara; BRAGANÇA, Ubiratan. Respeitável público, o show já vai começar!: as ilusões do grande circo neopentecostal brasileiro. 2. ed. São Gonçalo: Editora Contextualizar, 2015.

BRANDEN, Nathaniel. Menthal health versus mysticism and self-sacrifice. In: RAND, Ayn. The virtue of selfshness. New York: Signet, 1964. 
BRAUN, Theodor. Die religiöse Wahnbilgung. Tübingen: Mohr, 1906.

BROWN, Dan. Origin. New York: Doubleday, 2017.

CAILLOIS, Roger. L’homme et le sacré. 3. ed. Paris: Gallimard, 1988 (Folio/Essais).

CAMARA CASCUDO, Luis da. Civilização e Cultura. Belo Horizonte: Itatiaia, 1983. (Coleção Clássicos da Cultura Brasileira, v. 1)

CAMARGO, Marina von Zuben de Arruda; APRAHAMIAN, Ivan. Peculiaridades do sistema nervoso central. In: SERAFIM, Antonio de Pádua; SAFFI, Fabiana (Org.). Neuropsicologia forense. Porto Alegre: Artmed, 2015. p. 57-67.

CAMPOS JUNIOR, Luís de Castro. Pentecostalismo: sentidos da palavra divina. São Paulo: Ática, 1995. (As religiões na história)

CAMUS, Albert. O mito de Sísifo. Trad. Ari Roitman; Paulina Wacht. São Paulo: Best Bolso, 2010.

CANARIS, Claus-Wilhelm. Direitos fundamentais e direito privado. Trad. Ingo Wolfgang Sarlet; Paulo Mota Pinto. Coimbra: Almedina, 2012.

CANOTILHO, J. J. Gomes; MENDES, Gilmar Ferreira; SARLET, Ingo Wolfgang; STRECK, Lenio Luiz (Coord.). Comentários à Constituição do Brasil. São Paulo: Saraiva, 2014.

CAPOGRASSI, Giuseppe. La vita etica. A cura di Francesco Mercadante. Milano: Bompiani, 2008.

CARBONNIER, Jean. Sociologia jurídica. Trad. Diogo Leite de Campos. Coimbra: Almedina, 1979. 
CATROGA, Fernando. Entre deuses e Césares: secularização, laicidade e religião civil: uma perspectiva histórica. 2. ed. Coimbra: Almedina, 2010.

CESAR, Osorio. Misticismo e loucura: contribuição para o estudo das loucuras religiosas no Brasil. São Paulo: Oficinas Gráficas do Serviço de Assistência a Psicopatas, 1939.

CHINEllatO, Silmara Juny (Coord.). Código Civil Interpretado - Artigo por Artigo, Parágrafo por Parágrafo. Barueri: Manole, 2008.

CONSORTI, Pierluigi. Diritto e religione. 2 ed. Bari: Laterza, 2010.

CORDEIRO, António Manuel da Rocha e Menezes. Tratado de direito civil: parte geral; negócio jurídico. 4 ed. Coimbra: Almedina, 2017. v. 2.

. Tratado de direito civil: parte geral; pessoas. 3 ed. Coimbra: Almedina, 2011. v. 4.

. Da boa fé no direito civil. Coimbra: Almedina, 2011. (Teses de doutoramento)

COUSSIRAT-COUSTĖRE, Vincent. La jurisprudence de la Cour européenne des droits de l'homme. In: DUARTE, Bernardette (Coord.). Manifester sa religion: Droits et limites. Paris: L’Harmattan, 2011. p. 11-64.

COUTURE, Eduardo Juan. Fundamentos do Direito Processual Civil. Trad. Benedicto Gaccobini. São Paulo: Red Livros, 1999.

DALGALARRONDO, Paulo. Religião, psicopatologia e saúde mental. Porto Alegre: Artmed, 2008.

. Estudos sobre religião e saúde mental realizados no Brasil: histórico e perspectivas atuais. Revista de Psiquiatria Clínica, 34, supl. 1, p. 25-33, 2007. 
DAWKINS, Richard. Deus, um delírio. Trad. Fernanda Ravagnani. São Paulo: Companhia das Letras, 2007.

DINIZ, Maria Helena. Curso de Direito Civil brasileiro: direito de família. 22. ed. São Paulo: Saraiva, 2007. v. 5.

DUARTE, Bernardette. Le point de vue du Comité des droits de l'homme. In: DUARTE, Bernardette (Coord.). Manifester sa religion: Droits et limites. Paris: L'Harmattan, 2011, p. $65-102$.

DURKHEIM, Émile. As formas elementares da vida religiosa: o sistema totêmico na Austrália. Trad. Paulo Neves. São Paulo: Martins Fontes, 1996 (Coleção Tópicos).

O problema religioso e a dualidade da natureza humana. Debates do NER-Núcleo de Estudos de Religião da Universidade Federal do Rio Grande do Sul, Porto Alegre, ano 13, no 22, p. 27-61, jul.-dez. 2012.

DWORKIN, Ronald. Justiça para ouriços. Trad. Pedro Elói Duarte. Coimbra: Almedina, 2016.

. Religion without God. Cambrige: Harvard University Press, 2013.

. Levando os direitos a sério. Trad. Nelson Boeira. São Paulo: Martins Fontes, 2002.

D’AGOSTINO, Francesco. Diritto e religione. Roma: Aracne Editrice, 2013.

EAGLEMAN, David. Incógnito: as vidas secretas do cérebro. Trad. Ryta Vinagre. Rio de Janeiro: Rocco, 2012.

EPALZA, Mikel de. Pluralismo e tolerância, um modelo toledano? In: CARDAILLAC, Louis (Org.). Toledo, séculos XII-XIII: muçulmanos, cristãos e judeus: o saber e a 
tolerância. Trad. Lucy Magalhães. Rio de Janeiro, Jorge Zahar, 1992. p. 213-222. (Coleção Memória das Cidades)

ERELLE, Anna. Na pele de uma jihadista: a história real de uma jornalista recrutada pelo Estado Islâmico. Trad. Dorothée de Bruchard; Eduardo Brandão. São Paulo: Paralela, 2015 .

ESPINOSA, Baruch de. Breve tratado de Deus, do homem e do seu bem-estar. Trad. Emanuel Angelo da Rocha Fragoso; Luís César Guimarães Oliva. Belo Horizonte: Autêntica, 2014.

FERNANDES, Millôr. Millôr definitivo: a bíblia do caos. Porto Alegre: L\&PM, 2009.

FERRARI, Silvio. La Corte di Strasburgo e l'articolo 9 della Convenzioni europea: un'analisi quantitativa dela giurisprudenza. In: MAZZOLA, Roberto (Org.). Diritto $e$ religione in Europa: Rapporto sulla giurisprudenza dela Corte europea dei diritti dell'uomo in materia di libertà religiosa. Bologna: Il Mulino, 2012. p. 27-54.

FERREIRA FILHO, Manoel Gonçalves. Curso de Direito Constitucional. 19. ed. São Paulo: Saraiva, 2002.

. Direitos humanos fundamentais. 5. ed. São Paulo: Saraiva, 2002.

. A democracia possivel. São Paulo: Saraiva, 1972.

FEUERBACH, Ludwig. Preleções sobre a essência da religião. Trad. José da Silva Brandão. Petrópolis: Vozes, 2009. (Coleção Textos Filosóficos)

FOUCAULT, Michel. Doença mental e psicologia. 6. ed. Trad. Lilian Rose Shalders. Rio de Janeiro: Tempo Brasileiro, 2000. (Coleção Biblioteca Tempo Universitário, V. 11)

. Os anormais: curso no Collège de France (1974-1975). Trad. Eduardo Brandão. São Paulo: Martins Fontes, 2002. 
. História da loucura: na idade clássica. 9. ed. Trad. José Teixeira Coelho Netto. São Paulo: Perspectiva, 2010.

FOWLER, James. Stages of faith: The Psychology of Human Development and the Quest for Meaning. New York: HarperCollins Publishers, 1981.

FRANÇA, Rubens Limongi (Coord.). Enciclopédia Saraiva. São Paulo: Saraiva, 1977. v. 13.

FRANCISCO I, Papa. O nome de Deus é Misericórdia. Trad. Catarina Mourão. São Paulo: Planeta do Brasil, 2016.

. Amoris Laetitia. Exortação Apostólica Pós-Sinodal. Cidade do Vaticano, 2016.

Disponível em:

$<$ http://w2.vatican.va/content/dam/francesco/pdf/apost_exhortations/documents/papafrancesco_esortazione-ap_20160319_amoris-laetitia_po.pdf>.Acesso em: 30 out. 2017.

. Laudato Si’. Carta Encíclica. Cidade do Vaticano, 2015. Disponível em: $<$ http://w2.vatican.va/content/dam/francesco/pdf/encyclicals/documents/papafrancesco_20150524_enciclica-laudato-si_po.pdf>. Acesso em: 30 out. 2017.

FREUD, Sigmund. O mal-estar na civilização. Trad. Paulo César de Souza. São Paulo: Penguin Classics Companhia das Letras, 2011.

FUCCILO, Antonio. Giustizia e religione. Torino: G. Giappichelli Editore, 2011. v. 1. . Giustizia e religione. Torino: G. Giappichelli Editore, 2011. v. 2.

FUSTEL DE COULANGES, Numa Denis. A cidade antiga: estudo sobre o culto, o direito e as instituições da Grécia e de Roma. 2. ed. Trad. J. Cretella Jr.; Agnes Cretella. São Paulo: Editora Revista dos Tribunais, 2011. (RT Textos Fundamentais, 7) 
GAGLIANO, Pablo Stolze. O Contrato de Doação. $3^{\text {a }}$ ed. São Paulo: Saraiva, 2010.

GALILEI, Galileu. Ciência e fé. Trad. Carlos Arthur R. do Nascimento. São Paulo: Editora UNESP, 2009.

GOMES, Orlando. Introdução ao direito civil. 21. ed. Rio de Janeiro: Forense, 2016.

. Raízes históricas e sociológicas do Código Civil brasileiro. 2. ed. São Paulo: Martins Fontes, 2006. (Justiça e Direito)

. Direito de Família. 2. ed. Rio de Janeiro: Forense, 1976.

GONÇALVES, Carlos Roberto. Direito civil brasileiro: direito de família. São Paulo: Saraiva, 2005. v. 6.

GONÇALVES, Luiz da Cunha. Tratado de direito civil. 2. ed. 1. ed. bras. São Paulo: Max Limonad, 1955. v. 1. t. 1.

Tratado de direito civil. 2. ed. 1. ed. bras. São Paulo: Max Limonad, 1955. v. 2. t.

2.

GRIFFIN, Leslie C. Law and religion: cases and materials. 2 ed. Houston: Foundation Press, 2010.

GUERREIRO, Sara. As fronteiras da tolerância: liberdade religiosa e proselitismo na convenção europeia dos direitos do homem. Coimbra: Almedina, 2005.

GUILHERME, Luiz Fernando do Vale de Almeida. Código civil comentado e anotado. 2. ed. Barueri: Manole, 2017.

. Manual de Direito Civil. Barueri: Manole, 2016. 
GUIMARÃES, Octavio M. Da incapacidade natural. Revista dos Tribunais, São Paulo, v. 170, n. 461, 1947. Ora in: MENDES, Gilmar Ferreira; STOCO, Rui (Org.). Doutrinas essenciais: direito civil - parte geral (pessoas e domicílio). São Paulo: RT, 2011. v. 3. p. 593-595.

HABERMAS, Jürgen. Fé e saber. Trad. Fernando Costa Mattos. São Paulo: Editora UNESP, 2013.

. Teoria do agir comunicativo: sobre a crítica da razão funcionalista. Trad. Paulo Astor Soethe. São Paulo: WMF Martins Fontes, 2012. v. 2.

- Entre naturalismo e religião: estudos filosóficos. Trad. Flávio Bento Siebeneicher. Rio de Janeiro: Tempo Brasileiro, 2007. (Biblioteca Colégio do Brasil, 14)

HARRIS, Sam. Free will. New York: Free Press, 2012.

O fim da fé: religião, terrorismo e o futuro da razão. Trad. Pedro Serras Pereira. Lisboa: Tinta-da-China, 2007.

HARRIS, Sam; NAWAZ, Maajid. Islam and the future of tolerance: a dialogue. Cambridge: Harvard University Press, 2015.

HAUGHT, James A.. Perseguições religiosas: uma história do fanatismo e dos crimes religiosos. 3. ed. Trad. Bete Torii. Rio de Janeiro: Ediouro, 2003.

HEGEL, Georg Wilhelm Friedrich. Aphorismen aus der jenenser zeit. In: HOFFMEISTER, Johannes (Org.). Dokumente zu Hegels Entwicklung. Stuttgard-Bad Cannstat: Frommann, 1974.

HIRSI ALI, Ayaan. Herege: por que o islã precisa de uma reforma imediata. Trad. Laura Teixeira Motta; Jussara Simões. São Paulo: Companhia das Letras, 2015. 
. A virgem na jaula: um apelo à razão. Trad. Ivan Weizs Kuck. São Paulo: Companhia das Letras, 2008.

HITCHENS, Christopher. Deus não é grande: como a religião envenena tudo. Trad. George Schlesinger. São Paulo: Globo Livros, 2016.

HOBBES, Thomas. Leviatã: ou matéria, forma e poder de uma República eclesiástica civil. Trad. João Paulo Monteiro; Maria Beatriz Nizza da Silva; Cláudia Berliner; Eunice Ostrensky. São Paulo: Martins Fontes, 2014 (Clássicos Cambrige de Filosofia Política).

HOFFER, Eric. Fanatismo e movimentos de massa. Trad. Sylvia Jatobá. Rio de Janeiro: Lidador, 1968.

HÖRSTER, Heinrich Ewald. A parte geral do Código Civil português: teoria geral do direito civil. Coimbra: Almedina, 2000.

HOUELlEBECQ, Michel. Submissão. Trad. Rosa Freire d'Aguiar. Rio de Janeiro: Objetiva, 2015.

HOUTART, François. Mercado e religião. Trad. Claudia Berliner; Renata Cordeiro. São Paulo: Cortez, 2003.

HUMBOLDT, Wilhelm von. Os limites da ação do Estado: idéias para um ensaio a fim de determinar as fronteiras da eficácia do Estado. Trad. Jesualdo Correia. Rio de Janeiro: Topbooks, 2004.

HUME, David. História natural da religião. Trad. Jaimir Conte. São Paulo: Editora UNESP, 2005.

IDLER, Ellen L.; KASL, Stanislav V. Religon among disabled and nondisabled persons I: cross-sectional patterns in health practices, social activities, and well-being. Journal of Gerontology-The Gerontolofy Society of America, v. 52B, no 6, p. S295-S305, 1997. 
JOSSERAND, Louis. L'esprit des droits et de leur relativité: théorie dite de l'abus des droits. Librairie Dalloz: Paris, 1927.

JUNG, Carl Gustav. Psicologia e religião. 11. ed. Trad. Dom Matheus Ramalho Rocha. Petrópolis: Vozes, 2012.

KANT, Immanuel. A religião nos limites da simples razão. Trad. Artur Morão. Lisboa: Edições 70, 2008. (Textos Filosóficos, 34)

KELSEN, Hnas. A Democracia. 2. ed. Trad. Ivone Castilho Benedetti; Jefferson Luiz Camargo; marcelo Brandão Cipolla; Vera Barkow. São Paulo: Martins Fontes, 2000.

KIERKEGAARD, Søren. Temor e tremor. Trad. Torrieri Guimarães. São Paulo: Hemus, 2008 .

KOENIG, Harold G. (Ed.). Handbook of religion and mental health. San Diego: Academic Press, 1998.

KUNDERA, Milan. A festa da insignificância. Trad. Teresa Bulhões Carvalho da Fonseca. São Paulo: Companhia das Letras, 2014.

LANDHEER-CIESLAK, Christelle. La religion devant les juges français et québécois de droit civil. Brussels: Bruylant, 2008.

LARA, Silvia Hunold (Org.). Ordenações Filipinas: Livro V. São Paulo: Companhia das Letras, 1999. (Coleção Retratos do Brasil)

LEITE, Fábio Carvalho. Estado e religião: a liberdade religiosa no Brasil. Curitiba: Juruá, 2014 .

LEITE, Flávia Piva Almeida; RIBEIRO, Lauro Luiz Gomes; COSTA FILHO, Waldir Macieira da. Comentários ao Estatuto da Pessoa com Deficiência. São Paulo: Saraiva, 2016. 
LENOIR, Frédéric. Deus: sua história na epopeia humana. Trad. Véra Lucia dos Reis. Rio de Janeiro: Objetiva, 2013.

LILLA, Mark. The stillborn God: religion, politics, and the modern West. New York: Vintage Books, 2007.

. The shipwrecked mind: on political reaction. New York: New York Review Books, 2016.

LLOSA, Mario Vargas. O véu que não é um mero véu. O Estado de S. Paulo, São Paulo, 7 out. 2007, p. A22.

LOCKE, John. Carta acerca da tolerância. São Paulo: Abril Cultural, 1973. (Os Pensadores)

LOPEZ, Teresa Ancona. Exercício do direito e suas limitações: abuso do direito. In: NERY, Rosa Maria de Andrade; DONNINI, Rogério. Responsabilidade civil: estudos em homenagem ao Professor Rui Geraldo Camargo Viana. São Paulo: RT, 2009. p. 540-557.

. Princípio da precaução e evolução da responsabilidade civil. São Paulo: Quartier Latin, 2010.

A Resolução 24/2010 da Anvisa e a publicidade para o público infantil. In: RODAS, João Grandino (Coord.). Direito econômico e social: atualidades e reflexões sobre Direito concorrencial, do consumidor, do trabalho e tributário. São Paulo: RT, 2012. p. $273-282$.

LOTUFO NETO, Francisco. Psiquiatria e religião: a prevalência de transtornos mentais entre ministros religiosos. Tese (Livre-docência em Psiquiatria). Faculdade de Medicina, Universidade de São Paulo, São Paulo, 1997. 
MACHADO, Jónatas Eduardo Mendes. A jurisprudência constitucional portuguesa diante das ameaças à liberdade religiosa. Boletim da Faculdade de Direito-Universidade de Coimbra. vol. LXXXII, p. 65-134. Coimbra: Coimbra Editora, 2006.

- Liberdade religiosa numa comunidade constitucional inclusiva: dos direitos da verdade aos direitos dos cidadãos. Boletim da Faculdade de Direito-Universidade de Coimbra. Coimbra: Coimbra Editora, 1996.

MACHADO, Maria Costa Neves. Liberdade religiosa: uma questão de tolerância ou respeito? In: Revista da Faculdade de Direito-Universidade de São Paulo, São Paulo, v. 105, p. 743-765, 2010.

MACRİ, Gianfranco; PARISI, Marco; TOZZI, Valerio. Diritto civile e religioni. Bari: Laterza, 2013.

MAOMÉ. O Alcorão. 7. ed. Trad. Mansour Challita. Rio de Janeiro: Best Bolso, 2014.

MARCHETTI, Gloria. Interventi pubblici a sostengo delle famiglie nell'educazione dei minori. In: RAFFIOTTA, Edoardo Carlo; MIRAS, Antonio Pérez; LOZANO, Germán Manuel Teruel (Dir.). Desafios para los derechos de la persona ante el siglo XXI: familia y religión. Navarra: Thomson Reuters Aranzadi, 2013. p. 203-2010.

MARCUSE, Herbert. Repressive tolerance. Disponível em: $<$ ada.evergreen.edu/ arunc/texts/frankfurt/marcuse/tolerance.pdf $>$. Acesso em: 3 set. 2015.

MARTÍNEZ-TORRÓN, Javier. La (non) protezione dell'identitá religiosa dell'individuo nella giurisprudenza dela Corte di Strasburgod. In: MAZZOLA, Roberto (Org.). Diritto e religione in Europa: Rapporto sulla giurisprudenza dela Corte europea dei diritti dell'uomo in materia di libertà religiosa. Bologna: Il Mulino, 2012. p. 55-86.

MENDES, Gilmar Ferreira; BRANCO, Paulo Gustavo Gonet. Curso de Direito Constitucional. 9. ed. São Paulo: Saraiva, 2014. 
MENDONÇA, Antônio de Gouvêa. Protestantes, pentecostais e ecumênicos. São Bernardo do Campo: UMESP, 1997, 161.

MEIRELLES, Jussara Maria Leal de. O transtorno bipolar de humor e o ambiente socioeconômico que o propicia: uma leitura do regime de incapacidades. In: FACHIN, Luiz Edson; TEPEDINO, Gustavo (Org.). Diálogos sobre direito civil. Rio de Janeiro: Renovar, 2007. v. 2. p. 599-617.

MELLO, Marcos Bernardes de. Teoria do fato jurídico: plano da validade. 10 ed. São Paulo: Saraiva, 2010.

MOLIÈRE. Le médecin malgré lui. Paris, 1666. Disponível em: $<$ http://www.toutmoliere.net/IMG/pdf/medecin_malgre_lui.pdf >. Acesso em: 11 nov. 2017.

MONTESQUIEEU. De l'esprit des lois. Paris: Éditions Garnier Frères, 1973. t. I.

MORENTE, Manuel Garcia. Fundamentos de Filosofia: lições preliminares. 8. ed. Trad. Guilhermo de la Cruz Coronado. São Paulo: Mestre Jou, 1930.

MURAMOTO, Osamu. The role of the medial prefrontal cortex in human religious activity. Medical Hyphoteses, v. 62, $\mathrm{n}^{\mathrm{o}}$ 4. Elsevier, abr. 2004. Disponível em: $<$ sciencedirect.com.br>. Acesso em: 4 de abr. de 2016.

MURAT, Laure. O homem que se achava Napoleão: por uma história política da loucura. Trad. Paulo Neves. São Paulo, Três Estrelas, 2012.

NERY JÚNIOR, Nelson. Escolha esclarecida de tratamento médico por pacientes testemunhas de Jeová como exercício harmônico de direitos fundamentais. Parecer. São Paulo, 2009.

Direito de liberdade e consentimento informado: a possibilidade de se recursar tratamento médico em virtude de convicções religiosas. In: VILLAÇA AZEVEDO, 
Álvaro; LIGIERA, Wilson Ricardo (Coord.). Direitos do paciente. São Paulo: Saraiva, 2012. p. 383-446.

NOVAIS, Jorge Reis. As restrições aos direitos fundamentais não expressamente autorizadas pela Constituição. Coimbra: Coimbra Editora, 2003.

OHLER, Norman. High Hitler: como o uso de drogas pelo Führer e pelos nazistas ditou o ritmo do Terceiro Reich. Trad. Silvia Bittencourt. São Paulo: Planeta, 2017.

ONFRAY, Michel. Tratado de ateologia: física da metafísica. Trad. Monica Stahel. São Paulo: WMF Martins Fontes, 2007.

OZ, Amós. Judas. Trad. Paulo Geiger. São Paulo: Companhia das Letras, 2014.

. Como curar um fanático: Israel e Palestina: Entre o certo e o certo. Trad. Paulo Geiger. São Paulo: Companhia das Letras, 2016.

PALOMBA, Guido Arturo. Tratado de psiquiatria forense: civil e penal. São Paulo: Atheneu, 2003.

PASCHOAL, Janaína Conceição. Direito penal e religião: as várias interfaces de dois temas que aparentam ser estanques. Tese (Titularidade em Direito Penal) - Faculdade de Direito do Largo São Francisco, Universidade de São Paulo, São Paulo, 2017.

PAVINATTO, Tiago. Da condição do pródigo na sociedade de consumo. Revista de direito civil contemporâneo. n. 2. v. 2. p. 29-60. São Paulo: Revista dos Tribunais, jan.mar. 2015.

PEREIRA, Caio Mário da Silva. Instituições de direito civil: introdução ao direito civil; teoria geral do direito civil. 29. ed. atual. por Maria Celina Bodin de Moraes. Rio de Janeiro: Forense, 2016. v. 1. 
PEREIRA, Cláudio Luiz. Seguindo a voz de Deus: narrativas e etnografia em um caso de sacrifício de crianças - Salvador-Bahia, 1977/2001. Tese (Doutorado em Ciências Sociais) - Instituto de Filosofia e Ciências Humanas, Universidade Estadual de Campinas, Campinas, 2002.

PESSOA, Fernando. Poesia completa de Alberto Caieiro. São Paulo: Companhia das Letras, 2005.

Passagem das horas. In PESSOA, Fernando. Poemas de Álvaro de Campos. Disponível em: <http://www.dominiopublico.gov.br/download/texto/pe000010.pdf>. Acesso em: 10 nov. 2017.

PINHO, Rubim de. Fragmentos da psiquiatria transcultural. Salvador: EDUFBA, 2002.

PLUTARCO. Sobre a tagarelice; seguido de Sobre a demora da justiça divina; e Das doenças da alma e do corpo. Trad. Marina Echalar. São Paulo: Landy Editora, 2008.

PONTES DE MIRANDA, Francisco Cavalcanti. Tratado de direito privado. 2. ed. Rio de Janeiro: Borsoi, 1956. t. 7.

Tratado de direito privado. 2. ed. Rio de Janeiro: Borsoi, 1956. t. 9.

. Tratado das ações: ações constitutivas. 1. ed. atual. por Nelson Nery Junior; Georges Abboud. São Paulo: Editora Revista dos Tribunais, 2016. t. 4.

PORTER, Ray. Uma história social da loucura. Trad. Angela Melim. 2. ed. Rio de Janeiro: Jorge Zahar, 1991.

POWELL, Enoch. Speech delivered to a Conservative Association meeting in Birmingham on April 20 1962. Disponível em: < http://www.telegraph.co.uk/comment/3643823/EnochPowells-Rivers-of-Blood-speech.html>. Acesso em: 18 out. 2017. 
PREVIC, Fred H. The role of the extrapersonal brain systems in religious activity. Conciousness and Cognition, v. 15, $\mathrm{n}^{\mathrm{o}}$ 3, Elsevier, set. 2006. Disponível em: $<$ sciencedirect.com>. Acesso em: 2 mai. 2016.

PRIORE, Mary del. Do outro lado: a história do sobrenatural e do espiritismo. São Paulo: Planeta, 2014.

PUFENDORF, Samuel von. Of the nature and qualification religion in reference to civil society. Trad. Jodocus Crull. Indianapolis: Liberty Fund, 2002.

PULLMAN, Philip. O bom Jesus e o infame Cristo. Trad. Christian Schwartz. São Paulo: Companhia das Letras, 2010.

RAMOS, Henrique Cesar Monteiro Barahona. O "mandato divino" de Teixeira de Freitas: o jurista entre a loucura e a fé. In: SIMPÓSIO NACIONAL DE HISTÓRIA, XXVI, 2011, São Paulo. Anais do XXVI Simpósio Nacional de História - ANPUH. São Paulo: USP, 2011. Disponível em: $<$ http://www.snh2011.anpuh.org/resources/anais/14/1308185621_ARQUIVO_omandatodi vinodeteixeiradefreitas_ojuristaentreareligiaoeafe.pdf $>$. Acesso em: 3 out. 2014.

RAND, Ayn. Cântico. Trad. André Assi Barreto. Campinas: Vide Editorial, 2015.

RÁO, Vicente. Da capacidade civil da mulher casada. São Paulo: Saraiva, 1922. (Collecção Jurídica da Livraria Academica)

RODRIGUES, Raimundo Nina. O Alienado no direito civil brasileiro. 3. ed. São Paulo: Companhia Editora Nacional, 1939.

. As coletividades anormais. Brasília: Senado Federal, Conselho Editorial, 2006.

ROSENO, Marcelo. Estatuto da Pessoa com Deficiência e exercício de direitos políticos: elementos para uma abordagem garantista. In: Revista Jurídica da Presidência-Governo Federal, Brasília, v. 18, n. 116, p. 559-582, out. 2016/jan. 2017. 
ROSSITER, Lyle H. A mente esquerdista: as causas psicológicas da loucura política. Trad. Flávio Quintela. Campinas: Vide Editorial, 2016.

RUGGIERO, Roberto de. Instituições de direito civil. 7. ed. Trad. [...]. Campinas: Bookseller, 1999. v. 1.

RUSSELL, Bertrand. Por que não sou cristão e outros ensaios a respeito de religião e assuntos afins. Trad. Ana Ban. Porto Alegre: L\&PM Pocket, 2016.

. História da Filosofia ocidental: a filosofia moderna. Trad. Hugo Langone. Rio de Janeiro: Nova Fronteira, 2015. v. 3.

SAN TIAGO DANTAS, Francisco Clementino de. Programa de direito civil: aulas proferidas na Faculdade Nacional de Direito [1942-1945] - parte geral. Rio de Janeiro: Editora Rio, 1979.

SANTOS SARAIVA, F. R. dos. Novissimo Diccionario Latino-Portuguez: etymológico, prosodico, historico, geographico, mythologico, biographico, etc. 9. ed. Rio de Janeiro: Livraria Garnier, 1927.

SANTORO-PASSARELLI, Francesco. Teoria geral do direito civil. Trad. Manuel de Alarcão. Coimbra: Atlântida Editora, 1967.

SARAMAGO, José. Caim. São Paulo: Companhia das Letras, 2009.

SCAFF, Fernando Campos. Considerações sobre o poder familiar. In: SIMÃO, José Fernando; FUJITA, Jorge Shiguemitsu; CHINELLATO, Silmara Juny de Abreu; ZUCCHI, Maria Cristina (Org.). Direito de família no novo milênio: estudos em homenagem aos Professor Álvaro Villaça Azevedo. São Paulo: Atlas, 2010. p. 571-582. 
SCHIOPPA, Antonio Padoa. História do direito na Europa: da Idade Média à Idade Contemporânea. Trad. Marcos Marcionilo; Silvana Cobucci Leite. São Paulo: Martins Fontes, 2014.

SCLIAR, Moacyr. Manual da paixão solitária. São Paulo: Companhia das Letras, 2008. . Os vendilhões do Templo. São Paulo: Companhia das Letras, 2006.

SEIERSTAD, Åsne. Um de nós: a história de Anders Breivik e do mais chocante atentado terrorista da Noruega. Rio de Janeiro: Record, 2016.

SERAFIM, Antonio de Pádua; DUARTE, Éverton; ACHÁ, Maria Fernanda F.. Aspectos históricos da neuropsicologia clínica e forense. In: SERAFIM, Antonio de Pádua; SAFFI, Fabiana (Org.). Neuropsicologia forense. Porto Alegre: Artmed, 2015. p. 17-25.

SERAFIM, Antonio de Pádua; SAFFI, Fabiana. A perícia em saúde mental. In: SERAFIM, Antonio de Pádua; SAFFI, Fabiana (Org.). Neuropsicologia forense. Porto Alegre: Artmed, 2015. p. 46-56.

SERAFIM, Antonio de Pádua; MORAES, Ana Jô Jennings. Emoção. In: SERAFIM, Antonio de Pádua; SAFFI, Fabiana (Org.). Neuropsicologia forense. Porto Alegre: Artmed, 2015. p. 113-120.

SERAFIM, Antonio de Pádua; RIBEIRO, Aires Evandro José; MALLOY-DINIZ, Leandro F.. Funções executivas. In: SERAFIM, Antonio de Pádua; SAFFI, Fabiana (Org.). Neuropsicologia forense. Porto Alegre: Artmed, 2015. p. 121-129.

SERAFIM, Antonio de Pádua; D’ALCANTE, Carina Chaubet. Transtorno obsessivocompulsivo. In: SERAFIM, Antonio de Pádua; SAFFI, Fabiana (Org.). Neuropsicologia forense. Porto Alegre: Artmed, 2015. p. 189-196. 
SERAFIM, Antonio de Pádua; MARQUES, Natali Maia. Transtornos de personalidade. In: SERAFIM, Antonio de Pádua; SAFFI, Fabiana (Org.). Neuropsicologia forense. Porto Alegre: Artmed, 2015. p. 241-248.

SERPA LOPES, Miguel Maria. Curso de direito civil: introdução, parte geral e teoria dos negócios jurídicos. 4. ed. Rio de Janeiro: Freitas Bastos, 1962. v. 1.

SHERMER, Michael. Cérebro \& Crença. Trad. Eliana Rocha. São Paulo: JSN Editora, 2012.

SILVA, Ana Beatriz Barbosa. Mentes consumistas: do consumismo à compulsão por compras. São Paulo: Globo, 2014.

SILVA, Eliane Moura da. Repensando o fanatismo religioso: representações, conceitos e práticas contemporâneas. Campinas: IFCH/UNICAMP, 2004. (Publicação de circulação interna Primeira Versão, t. 126)

SILVA, Ivan de Oliveira. Relação de consumo religiosa: a vulnerabilidade do fielconsumidor e a sua tutela por meio do Código de Defesa do Consumidor. São Paulo: Atlas, 2012.

SILVA, José Afonso da. Curso de direito constitucional positivo. 22. ed. São Paulo: Malheiros, 2003.

SINNER, Rudolf von. The churches and democracy in Brazil: towards a public theology focused on citizenship. Eugene: WIPF and stock Publishers, 2012.

SOCIEDADE BÍBLICA CATÓLICA INTERNACIONAL. Bíblia sagrada. Trad. Ivo Storniolo; Euclides Martins Balancin; José Luiz Gonzaga do Prado. Ed. pastoral. São Paulo: Paulus, 1998. 
SOUSA, Felipe Oliveira de. Razão prática, justificação da autoridade e o dever instrumental de obedecer. Revista Brasileira de Filosofia-RFB-Instituto Brasileiro de Filosofia, São Paulo: Marcial Pons, ano 62, v. 239, 2013, p. 135-168.

SUPIOT, Alain. $O$ espírito de Filadélfia: a justiça social diante do mercado total. Trad. Tânia do Valle Tschiedel. Porto Alegre: Sulina, 2014.

. Homo juridicus: ensaio sobre a função antropológica do Direito. Trad. Maria Ermantina de Almeida Prado Galvão. São Paulo: Martins Fontes, 2007. (Justiça e Direito.)

SZASZ, Thomas S. O mito da doença mental. Trad. Irley Franco; Carlos Roberto Oliveira. São Paulo: Círculo do Livro, 1974.

- A fabricação da loucura: um estudo comparativo entre a inquisição e o movimento de saúde mental. Trad. Dante Moreira leite. Rio de Janeiro: Zahar, 1976.

TARANTO, Salvatore. Diritto e religioni nelle democrazie contemporanee: una prospettiva normativa. Napoli: Edizioni Scientifiche Italiane, 2010.

TAYLOR, Kathleen. Brainwashing: the science of thought control. New York: Oxford University Press, 2004.

TEIXEIRA DE FREITAS, Augusto. Vocabulario juridico. Rio de Janeiro: Garnier, 1882.

TERAOKA, Thiago Massao Cortizo. A liberdade religiosa no Direito Constitucional brasileiro. Tese (Doutorado em Direito do Estado) - Faculdade de Direito do Largo São Francisco, Universidade de São Paulo, São Paulo, 2010.

THOREAU, Henry Davi. A desobediência civil. Trad. José Geraldo Couto. São Paulo: Penguin Classics Companhia das Letras, 2012. (Grandes ideias)

TOCQUEVILLE, Alexis de. A Democracia na América: sentimentos e opiniões: de uma profusão de sentimentos e opiniões que o estado social democrático fez nascer entre os 
americanos. L. 2. 2. ed. Trad. Eduardo Brandão. São Paulo: Martins Fontes, 2014. (Coleção Paideia)

VENOSA, Sílvio de Salvo. Direito civil: parte geral. 11. ed. São Paulo: Atlas, 2011. v. 1. Direito civil: direito de família. 11. ed. São Paulo: Atlas, 2011. v. 6.

VIEIRA, Patrícia Ruy. A interdição civil no direito brasileiro. In: MENDES, Gilmar Ferreira; STOCO, Rui (Org.). Doutrinas essenciais: direito civil - parte geral (pessoas e domicílio). São Paulo: RT, 2011. v. 3. p. 597-630.

VILLAÇA AZEVEDO, Álvaro. Autonomia do paciente e direito de escolha de tratamento médico sem transfusão de sangue. In: VILLAÇA AZEVEDO, Álvaro; LIGIERA, Wilson Ricardo (Coord.). Direitos do paciente. São Paulo: Saraiva, 2012. p. 271-302.

VOEGELIN, Eric. Hitler e os Alemães. Trad. Elpídio Mário Dantas Fonseca. São Paulo: É Realizações Editora, 2008.

VOLTAIRE. Tratado sobre a tolerância: a propósito da morte de Jean Calas. 2. ed. Trad. Paulo Neves. São Paulo: Martins Fontes, 2000. (Coleção Clássicos)

WALZER, Michael. Da tolerância. Trad. Almiro Pisetta. São Paulo: Martins Fontes, 1999.

WEBER, Max. A ética protestante e o espirito do capitalismo. 2. ed. Trad. M. Irene de Q. F. Szmrecsányi; Tamás J. M. K. Szmrecsányi. São Paulo: Cengage Learning, 2010.

WEINGARTNER NETO, Jayme. Liberdade Religiosa na Constituição: fundamentalismo, pluralismo, crenças, cultos. Porto Alegre: Livraria do Advogado, 2007.

WEISS, Michael; HASSAN, Hassan. Estado Islâmico: desvendando o exército do terror. Trad. Jorge Ritter. São Paulo: Seoman, 2015. 
WERNER, Hermann. Kann das Christentum Geisteskrank machen? Askona: Schmidtz, 1906.

WRIGHT, Lawrence. A prisão da fé: Cientologia, celebridades e Hollywood. Trad. Laura Motta; Denise Bottmann. São Paulo: Companhia das Letras, 2013.

ZAGREBELSKY, Gustavo. A crucificação e a democracia. Trad. Monica de Sanctis Viana. São Paulo: Saraiva, 2011.

\section{Noticiário:}

A CEGUEIRA da tolerância. Veja, edição 2389, ano 47, n 36, p. 76-77, 3 set. 2014.

ATENTADOS terroristas em Barcelona e Cambrils. El País. Disponível em: $<$ https://brasil.elpais.com/brasil/2017/08/17/internacional/1502987924_138296.html>. Acesso em 30 nov. 2017.

ATENTADOS terroristas na Bélgica deixaram dezenas de mortos e feridos. G1. Disponível em: $\quad<$ http://g1.globo.com/mundo/noticia/2016/03/aeroporto-de-bruxela-na-belgicaregistra-explosoes.html>. Acesso em 30 nov. 2017.

ALCÂNTARA, Eurípedes. A profecia da Tolerância. Veja, edição 2409, ano 48, nº 3, p. 70-71, 21 jan. 2015.

BIONDANI, Paolo. Vanna Marchi Marchi, le testimonianze delle vittime. Corriere dela sera.it. Disponível em:

$<$ http://www.corriere.it/Primo_Piano/Cronache/2002/01_Gennaio/25/vanna.shtml $>$. Acesso em: 20 out. 2017.

BRONZATTO, Thiago. A Guantánamo tupiniquim. Veja, edição 2543, ano 50, nº 33, p. 52-57, 16 ago. 2017. 
CARNEIRO, Felipe. Os assassinos da inocência. Veja, edição 2409, ano 48, nº 3, p. 61, 21 jan. 2015.

. O apelo da insensatez. Veja, edição 2408, ano48, nº 2, p. 70-71, 14 jan. 2015.

COUTINHO, Leonardo. A ameaça radical: entrevista com Rodrigo Jalloul. Veja, edição 2521, ano 50, no 11, p. 15-17, 15 mar. 2017.

DEODORO, Juliana. Jesus salva: Fiéis de igrejas neopentecostais abandonam tratamento médico e, quando a condição deles piora, recorrem ao sistema público de saúde - que é sustentado pelo mesmo Estado que isenta as igrejas de impostos e permite construção de templos irregulares. Galileu, edição 298, p. 38-49, mai. 2016.

DIAS, Tatiana de Mello. Fundamentalismo religioso pode ser tratado como doença mental, diz neurocientista. Disponível em: $<$ http://revistagalileu.globo.com/Revista/Common/0,_EMI339436-17770,00FUNDAMENTALISMO+RELIGIOSO+PODE+SER+TRATADO+COMO+DOENCA+M ENTAL+DIZ+NEUROCIEN.html>. Acesso em: 22 set. 2017.

ESTADO Islâmico reivindica atentado terrorista em Londres. $O$ Globo. Disponível em: $<$ https://oglobo.globo.com/mundo/estado-islamico-reivindica-atentado-em-metro-delondres-21827865>. Acesso em 30 nov. 2017.

FARIAS, Adriana Preso por uma paixão. Veja São Paulo, ano 49, n 17, p. 24-26, 27 abr. 2016.

GRYZINSKI, Vilma. A tirania do silêncio. Veja, edição 2408, ano 48, n 2, p. 68-69, 14 jan. 2015.

KUNZIG, Robert. Os novos europeus. National Geographic Brasil, ano 17, nº 199, p.2249, out. 2016. 
LOPES, Adriana Dias. Qual é a origem da Fé? Veja, edição 2449, n 43, p. 85-87, 28 out. 2015.

LUCCHESI, Renata. Dos escombros da intolerância. Veja, edição 2472, ano 49, nº 14, p. 70-71, 6 abr. 2016.

MÃE diz que matou filha para 'tirar o demônio'. O Estado de S. Paulo, São Paulo, 31 jul. 2014, p. A16.

NORTE, Diego Braga. Um terror sem fim. Veja, edição 2489, ano 49, no 31, p. 51, 3 ago. 2016.

NUBLAT, Johanna. O massacre dos jovens. Veja, edição 2532, ano 50, nº 22, p. 78-81, 31 mai. 2017.

PRENGAMAN, Peter; WEISS, Mitch; MOHR, Holbrook. Como a igreja Word of Faith Fellowship entrou no Brasil e cresceu. Associated Press. Disponível em: $<$ http://brasil.estadao.com.br/noticias/geral,como-a-igreja-word-of-faith-fellowship-entroue-cresceu-no-brasil,70001904304>. Acesso em: 20 out. 2017.

ROSE, Flemming. A expressão não pode ter limites. Veja, edição 2409, ano 48, nº 3, p. 64 65,21 jan. 2015.

SARAMAGO, José. O fator Deus. Folha Online. Disponível em: $<$ http://www1.folha.uol.com.br/folha/mundo/ult94u29519.shtml>. Acesso em 19 set. 2017.

TAVARES, Flávia. Vamos orar gente? Época, no 849, p. 46-51, 8 set. 2014.

TEIXEIRA, Duda. A batalha papal. Veja, edição 2519, ano 50, nº 9, p. 52-54, 1 mar. 2017. . Os mártires ao pé da cruz. Veja, edição 2472, ano 49, nº 14, p. 66-69, 6 abr. 2016. 
. Uma sombra sobre a Europa. Veja, edição 2453, ano 48, no 47, p. 70-77, 25 nov. 2015.

TEIXEIRA, Duda; CARNEIRO, Felipe. A indignação do mundo contra as trevas. Veja, edição 2408, ano 48, nº 2, p. 52-66, 14 jan. 2015.

TEIXEIRA, Duda; WATKINS, Nathalia. Letais contra inocentes desarmados. Veja, edição 2453, ano 48, no 47, p. 86-95, 25 nov. 2015.

TREVISAN, Cláudia; LEOPOLDO, Ricardo. Atropelamento em ciclovia tratado como ato terrorista mata ao menos oito em Nova York. O Estado de S. Paulo, Disponível em: $<$ http://internacional.estadao.com.br/noticias/geral,policia-de-nova-york-investiga-tiroteioem-manhattan,70002067872>. Acesso em 31 out. 2017.

VANCE, Erik. A mente que cura. National Geographic Brasil, ano 17, $\mathrm{n}^{\mathrm{o}}$ 201, p. 24-45, dez. 2016.

VEIGA, Edison. A tragédia anunciada na Turquia. Veja, edição 2485, ano 49, n²7, p. 6465, 6 jul. 2016.

VEIGA, Edison; BRANDÃO, Raquel. Papa diz que Teoria da Evolução e Big Bang são corretos. O Estado de S. Paulo, São Paulo, 29 out. 2014, p. A 23.

WATKINS, Nathalia. Os dois lados do terror. Veja, edição 2438, ano 48, n 32, p. 66-67, 12 ago. 2015.

. Não vê quem não quer. Veja, edição 2414, ano 48, nº 8, p. 65-65, 25 fev. 2015.

. A Europa contra o mal. Veja, edição 2409, ano 48, nº 3, p. 57-60, 21 jan. 2015.

. O fascismo em nome de Alá. Veja, edição 2408, ano 48, no 2, p. 72-74, 14 jan. 2015. 
WATKINS, Nathalia; COUTINHO, Leonardo. Um atropelo à humanidade. Veja, edição 2487, ano 49, no 29, p. 60-63, 20 jul. 2016.

WOLF, Eduardo. Não temos medo. Veja, edição 2409, ano 48, nº 3, p. 72-73, 21 jan. 2015.

\section{Documentários:}

JESUS camp. Direção e Produção: Heidi Ewing; Rachel Grady. Devils Lake (US): Heidi Ewing; Rachel Grady, 2006. Disponível em Netflix.

ONE of us. Direção e Produção: Heidi Ewing; Rachel Grady. New York (US): Netflix, 2017. 